\title{
Revoltas camponesas no Brasil escravista: a 'Guerra dos Maribondos' (Pernambuco, 1851-1852)
}

Peasant rebellions in Brazilian slave based society: the 'War of the Hornets' (Pernambuco, 1851-1852)

Guillermo de Jesus Palacios y Olivares

Professor do Colegio do México

\begin{abstract}
Resumo
A "Guerra dos Marimbondos" foi um levante de homens livres e pobres, camponeses - ou agricultores de subsistência, se se quer - na sua maiora, inconformados e alarmados com a promulgação, em 1851, do Regulamento do Registro dos Nascimentos e Óbitos no Império e, em menor grau, da Lei do censo. 0 Registro foi rapidamente apelidado de "Lei do Cativeiro", pela crença popular de que, coincidindo com as leis que determinavam o fim da importação de mão-de-obra africana escrava, destinava-se na verdade a recuperar para o escravismo uma ampla camada da população que não tinha, até então, sido objeto da atenção por parte do Estado ou dos proprietários das plantations açucareiras da zona da mata nordestina.
\end{abstract}

\begin{abstract}
The "War of the Hornets" was a rebellion of the free poor people, peasants mostly or, if one prefers, agricultural laborers. The population, startled and scared, rose against the 1851 Imperial Decree on Registration of Newborns and Deceased and, in a lesser degree, against the Decree that ordered the implementation of a National Census. The first one became then known as "Law of Captivity". According to popular belief, as the decree was passed almost simultaneously as the Law that prohibited the African slave trade to Brazil, its main goal was in fact the enslavement of large portions of the population; groups that, until that moment, had neither received any attention from the State, nor from the Northeast sugar plantation owners.
\end{abstract}

\section{Palavras-chave}

agricultura, homens livres pobres, escravidão, revolta / rebelião, Pernambuco, Segundo Reinado.

\section{Keywords}

agriculture, poor free people, slavery, uprising / rebellion, Pernambuco, Second Reign 
1

Palacios, G., "Campesinato e escravidão: uma proposta de periodização para a história dos cultvadores livres e pobres do Nordeste Oriental do Brasil, c.1700-1875", em Dados. Revista de Ciências Sociais, v. 30, n 3 (1987), pp. 325-353.

\section{2}

Palacios, G., "Peasantry and Slavery. A

Contribution to the History of the Free Poor Planters from Pernambuco, c. 1700-1817". PhD Dissertation. Princeton University, 1993, 2 vol. Publicada em espanhol como Cultivadores libres, Estado y crisis de la esclavitud en Brasil en la época de la Revolución industrial. México, El Colegio de México/Fondo de Cultura Económica, 1998. 355 pp., e traduzida ao português como Campesinato e escravidão no Brasil: agricultores pobres e livres na Capitania Geral de Pernambuco, 1700-1817. Brasilia, Editora da Universidade de Brasilia, 2004. 380 pp. As citações a este trabalho no texto a seguir referemse à edição brasileira.

\section{Advertência}

Este texto foi escrito, numa primeira versão, em fins de 1984, com ajuda de uma bolsa de pesquisa do CNPq, quando me desempenhava como professor-investigador do Curso de Pós-Graduação em Desenvolvimento Agrícola (CPDA), da Universidade Federal Rural do Rio de Janeiro. Usei basicamente o corpo documental referente ao movimento dos "Maribondos" publicado ao longo de 1852-1853 pelo Diário de Pernambuco e o material de arquivo disponivel no Arquivo Estadual de Pernambuco. Supunha naquele momento, seguindo informações de outros historiadores, que a documentação original havia-se perdido (as cópias foram de fato extraviadas em Pernambuco, mas os originais localizados posteriormente no Arquivo Nacional do Rio de Janeiro). A pesquisa rendeu vários frutos, entre outros, versões sucessivas do texto, uma proposta de periodização para a história dos agricultores livres e pobres do Nordeste Oriental, ${ }^{1}$ e, por fim, uma tese de doutorado. ${ }^{2}$ Todos esses trabalhos estão referidos na versão 'atualizada' de "A 'Guerra dos Maribondos" que se apresenta a seguir. Não acontece o mesmo com outros estudos referentes ao tema dos livres e pobres que têm sido produzidos desde o longínquo ano da redação original do presente trabalho, em parte pelo próprio abandono de que o texto foi objeto até esta sua derradeira resurreição, devida à leitura generosa da versão mecanuscrita feita pelos editores do Almanak Brasiliense; em parte também porque a incorporação do que agora (mas não no momento da pesquisa original) constitui um corpus estabelecido na historiografia sobre os livres e pobres do Brasil oitocentista, seria praticamente impossivel. Agradeço a compreensão.

GP

Cidade do México, julho de 2005 
"1852. Guerra dos Maribondos. A 10. de Janeiro rebenta no municipio de Pau-d'Alho, o movimento sedicioso conhecido pelo nome de Guerra dos Maribondos, cujo fito era impedir a execução do decreto imperial No. 798, de 18 de junho de 1851, decreto que tomava obrigatório, nas paroquias, o registro de nascimentos e de Óbitos. 0 movimento alastrou-se por vários municípios da Província e pela Província da Paraiba, onde tomou o nome de Ronco-da-Abelha. O govêrno enviou fortes contingentes para o debelar, mas a pacificação foi devida ao missionário capuchinho Frei Caetano da Messina".

Mário de Melo, "Síntese cronológica de Pernambuco" em Revista do Instituto Arqueológico, Histórico e Geográfico Pernambucano, v. XXXVIII (1943), pp.85-86.

"Maribondo. Espécie de insecto ou vespa muito vulgar, bravia, de ferrada penetrante, aguda, que imediatamente produz inchação e muitas dores".

E.A. Pereira da Costa, "Apontamentos para um vocabulário pernambucano de termos e phrases populares e de vocabulos vernáculos correntes no Estado com accepções diferentes", em ibid, v.XXXIV (1936), Nos.159-162, p.459. 
Decretos n. 797 e 798 de 18 de junho de 1851. Mandam, respectivamente, 'executar o regulamento para a organização do Censo Geral do Império', e 'executar o Regulamento do registro de nascimentos e óbitos', em Coleção das Leis do Império do Brazil de 1850, Tomo 14 (1851), Parte 2a., pp.161-174. Sobre as vicissitudes do emprego do termo "camponês" na historiografía brasileira, cf. G. Palacios, "Campesinato e historiografia no Brasil. Comentários sobre algumas obras notáveis", em Bib - Boletim Informativo e Bibliográfico em Ciências Sociais. ANPOCS, Rio de Janeiro, n. 35, $1^{\circ}$ semestre de 1993, pp. $41-58$

Eisenberg, Peter L., The Sugar Industry in Pernambuco. 1840-1910. Modernization without Change. Berkeley, University of California Press, 1974, p.196.

Relatório Apresentado a Assembléia Geral Legislativa pelo Ministro e Secretario de Estado dos Negócios do Império, 1852. p.18. A revolta em Minas, estranhamente ausente do Relatório acima, foi contudo acompanhada durante várias semanas pelo correspondente do Diário de Pernambuco nessa Província, sobretudo ao longo de Janeiro de 1852. Cf. Diário de Pernambuco (de agora em diante DP), janeiro de 1852, passim.
Como informa uma das citações do epigrafe, a "Guerra dos Maribondos" (denominação de uso restrito aos trabalhos do Mário Melo, mas aqui adotada pela facilidade de identificação da revolta e pelo conteúdo significante do termo) foi um levante de homens livres e pobres, camponeses - ou agricultores de subsistência, se se quer- na sua maioria, inconformados e alarmados com a promulgação, em 1851, do Regulamento do Registro dos Nascimentos e Óbitos no Império e, em menor grau, da Lei do Censo. ${ }^{3} 0$ Registro foi rapidamente apelidado de "Lei do Cativeiro", pela crença popular de que, coincidindo com as leis que determinavam o fim da importação de mão-de-obra africana escrava, destinava-se na verdade a recuperar para o escravismo uma ampla camada da população que não tinha, até então, sido objeto da atenção por parte do Estado ou dos proprietários das plantations açucareiras da zona da mata nordestina: os homens e as mulheres livres e pobres, entre os quais predominavam os agricultores não escravos. 0 interesse pelo assunto surgiu durante um período de trabalho de campo no agreste de Pernambuco. Procurando documentação sobre a história da agricultura de subsistência na região, na metade do século XIX, foram encontradas diversas referências ao que parecia ter sido uma breve e obscura revolta de pequenos agricultores livres, que teria acontecido em duas fases temporais: em torno de 1851/52 e nos anos de transição do Império à República. Este texto ocupa-se apenas do primeiro período.

Durante a revisão da literatura referente à época e região, surpreendime com a releitura do livro de Peter Eisenberg sobre a economia açucareira de Pernambuco, pois para meu espanto o autor fazia referência a uma revolta de "vagabundos", que se teria espalhado pela maior parte dos municípios açucareiros em 1851, segundo ele provocada pelo temor dos "homens de cor" de virem a ser escravizados através do Registro de Nascimentos e Óbitos. ${ }^{4}$ Constatando que eu estava errado em pensar que se tratava de um movimento circunscrito apenas às áreas de agricultura de subsistência do agreste pernambucano, e que Eisenberg pecava em igual medida ao supor que se encontrava limitado à região açucareira, acudi à documentação ministerial desses anos, principalmente os papeis dos Ministérios dos Negócios do Império e da Justiça, onde encontrei informações mais abrangentes com relação à revolta. Na realidade, tratava-se de um movimento que tinha aparecido entre os meses de dezembro de 1851 e fevereiro de 1852 , nas províncias de Pernambuco, Alagoas, Paraiba, Sergipe, Ceará e Minas Gerais. ${ }^{5}$ Com a relativa exceção desta última, parecia ser, pois, um movimento regional (muito embora, como se sabe, o norte de Minas tem sido freqüentemente associado à região Nordeste), possivelmente enquadrável dentro do complexo processo de transição que as provincias nordestinas iniciavam então em direção à constituição de um novo sistema de controle social do trabalho que substituísse o escravismo. Contudo, independentemente do universo geral da revolta, o foco era Pernambuco, e foi nessa província onde a conflagração provocada pelo Regulamento do Registro deu lugar aos mais alarmados temores das autoridades e dos proprietários de terras, tanto pela sua dimensão efetivamente maior, quanto -e sobretudo- pelo medo ainda vicejante entre a classe politica conservadora e os senhores de engenho da Zona da Mata, de que qualquer movimento de protesto redundasse na reativação do fogo morto da Revolução Praieira.

Os temores, no entanto, eram infundados. Embora altas figuras da administração provincial pernambucana, conservadores e/ou reacionários 
Figueira de Mello era, na época, a bête noire da oposição liberal pernambucana, por causa dos excessos por ele cometidos ou ordenados durante a cruenta repressão da insurreição praieira. Homem de extrema direita, com veleidades de intelectual e membro de sociedades literárias, foi também autor - entre outras obras - de uma muito lida e documentada Chronica da Rebelião Praieira em 1848 e 1849. Rio de Janeiro, Typographia do Brazil de J.J. da Rocha, 1850.

Inácio Bento de Loyola tinha sido redator do diário liberal A Voz do Brasil. Já Castro Tavares dirigiu o Guarda Nacional, da mesma tendência, foi deputado geral e professor titular da Faculdade de Direito do Recife. Cf. Carneiro, op.cit., pp. 176,179.

Relatório do Presidente da Provincia de Pernambuco, 1852, p.3 recalcitrantes como o Chefe da Policia, desembargador Jerónimo Martiniano Figueira de Mello, ${ }^{6}$ defendessem até o último momento a tese da 'manipulação' dos homens livres e pobres pelos ex-praieiros, estes, através de Jerónimo Vilela de Castro Tavares e Inácio Bento de Loyola, figuras de primeira linha do levantamento de $1848{ }_{1}^{7}$ não só negaram qualquer envolvimento com os distúrbios como que se ofereceram a marchar junto às tropas do governo conservador para sufocar uma revolta que, aos seus olhos de vanguarda liberal moderna, parecia estar constituída pela ralé reacionária do estrato mais baixo da sociedade pernambucana que queria opor-se ao progresso representado pelo Registro e pela estatística do Censo. Porém, o Presidente da Província, Vitor de Oliveira, homem de tensas relações com seu Secretário de Polícia pela sua moderação e insistente negativa em ver praieiros escondidos debaixo da cama, deu a palavra final sobre os acontecimentos na sua Província no Relatório de 1852:

"Resta dizer em honra de todos os Pernambucanos, que semelhantes movimentos não denunciaram intervenção de algum partido politico, e foi agradável observar que aquele, sobre que parecia ter-se querido fazer pairar alguma suspeita, repeliu com declarações francas, e por fatos não equivocos toda a opinião falsa que contra ele se podesse formar a esse respeito."8

Esta notável aliança de conservadores e liberais contra os homens livres e pobres, isto é, a aliança de inimigos políticos de uma mesma classe contra um grupo social que na sua ótica carecia de legitimidade para agir politicamente quando sua participação não se enquadrava nas estratégias e/ou nos objetivos dos setores tradicionalmente no comando do poder, será certamente um dos temas a serem analisados neste texto. A revolta contra o Registro de Nascimentos e Óbitos foi, em si, um movimento completamente desprovido de glória e de atos heróicos. Talvez seja por isso que, excetuando as obras já citadas de Eisenberg e de Mario de Melo, onde a 'Guerra dos Maribondos' aparece em raquíticos parágrafos, nenhum outro trabalho de história do período, pelo menos nenhum razoavelmente conhecido, faça a menor menção aos fatos aqui focalizados. E, dentro de certa lógica, com toda razão: ao lado da Praieira, da 'Guerra dos Cabanos', da 'Sabinada', da 'Cabanagem', da 'Setembrizada', da conflagração de 'QuebraKilos', e de tantas outras guerras e revoltas que agitaram o Nordeste do Brasil durante o Primeiro Reinado e a Regência, a sublevação contra o Registro de Nascimentos e Óbitos foi um pálido não-acontecimento para os seletivos olhos da historiografia nacional. Trata-se, de fato, de um revolta aparentemente sem a menor importância. Não foi, sequer, um movimento sangrento: o saldo final das suas raras e patéticas batalhas alcançou a ridícula soma de 12 mortos e 15 feridos, com o atenuante -agravante no caso de uma revolta- de que vários desses atos violentos foram praticados sem relação direta com o movimento e sim como ajustes de contas entre adversários políticos ou 'privados' que aproveitaram a poeira dos 'Maribondos' para saldarem haveres e deveres. De resto, dois soldados punidos por 'comportamento inconveniente' quando da ocupação da vila do Limoeiro, no agreste setentrional de Pernambuco- detenções escassas e passageiras e uma briga escandalosa entre o Presidente da Província e seu Chefe de Policia -, que se queixava de que o primeiro, além de 'frouxo' com os liberais, não deixava-o aparecer para a imprensa, diminuindo-Ihe os méritos no combate aos revoltosos. $E$, por fim, uma generosa recompensa oferecida 
9

Palacios, G. "Campesinato e escravidão", pp. $345-348$. a frei Caetano de Messina, o capuchinho que chefiou as missões de 'pacificação' dos insurretos, como seu antecessor no comando da ordem, Frei Plácido de Messina, havia 'pacificado' o que restou, no final, dos cabanos. Estranha especialização, essa dos frades. Ganharam também os curas e vigários das Paróquias, que com o rápido e estrondoso desenrolar dos fatos conseguiram manter ainda por muito tempo o monopólio do registro tradicional dos vivos e dos mortos, que Ihes rendia, além das pequenas taxas pagas pelas famílias, um generoso subsidio governamental. Ah, sim, uma outra coisa: a 'Guerra dos Maribondos' - na batalha de 1852- foi 'ganha' pelos livres e pobres, que forçaram o impávido Império a capitular e suspender a aplicação do Registro dos Nascimentos e Óbitos por mais de quarenta anos, assim como conseguiram deter por mais duas décadas as tentativas do Estado de os contar. Finalmente, neste breve balanço da revolta, last but not least, liberais e conservadores descobriram com grande alvoroço nos livres e pobres e, sobretudo, nos agricultores autônomos e seus circunstanciais aliados, um inimigo de classe digno de servir como patamar para consolidar a pacificação dos grupos dirigentes da sociedade agraria, e capaz de mostrar a necessidade histórica da conciliação dos detentores do poder.

Contudo, a pesquisa nunca esteve orientada no sentido de estudar uma revolta popular contra o Estado imperial em função dos seus resultados, nem da sua eventual historicidade plena. Pelo contrário, o que despertou a atenção foi precisamente a relativa insignificância dos fatos, a mínima importância dos seus protagonistas centrais, a sobrevivência de um episódio aparentemente irrelevante (mas eles não fazem parte, também, da história?), a indiscutivel falta de glamour na motivação dos atores principais ao encenarem uma revolta contra um regulamento escuro, certamente trivial na vida de qualquer nação civilizada. Sobretudo se comparado com o conjunto de leis de deslumbrante grandeza promulgado por esses anos. Em primeiríssimo lugar a Lei Eusébio de Queiroz, que fechava definitivamente a entrada de mão-de-obra africana; logo a seguir a famigerada, muito citada e pouco estudada Lei do Terras, e um pouco depois, meio escondida, a drástica reformulação do Regulamento da Guarda Nacional. Mas será que o Registro do Nascimentos e Óbitos -e seu apêndice, a Lei do Censo-, não faziam parte também, e parte importante, embora puramente 'operacional', de um mesmo projeto 'inercial' de repressão institucional contra os segmentos de pobres e livres do Brasil escravista, acrescido ainda pelas sucessivas leis favorecendo a entrada maciça de imigrantes e de capital estrangeiro e colocando ao mesmo tempo barreiras insalváveis à propriedade da terra por parte dos recém chegados ao mercado? ${ }^{9}$

Os sublevados da 'Guerra dos Maribondos' se levantaram contra uma série de acontecimentos que começaram a ocorrer por volta de 1850, e que representavam para eles -e não para os senhores de escravos, nem para os escravos, não para o capital, nem para o processo de acumulação, sinais evidentes de que uma grande mudança estava a caminho, e que essa mudança, seria no fundo concretizada às suas próprias expensas. Eles, homens e mulheres pobres e livres do Nordeste do Brasil, agricultores autônomos de base camponesa, eram a primeira linha de reserva de mão-deobra para as plantations no inicio da crise terminal do escravismo.

A 'Guerra dos Maribondos' coincide com os primórdios do processo de aparelhamento do Estado para enfrentar tarefas tão importantes na construção de uma economia que se adaptasse às mudanças do capitalismo 
10

José de Souza Martins tocou de leve nesse problema. Cf. o seu notável 0 Cativeiro da Terra. São Paulo, Hucitec, 3a ed., 1986, p.12. no âmbito mundial como a estruturação de um mercado de trabalho livre. Nesse contexto, o movimento significou um ato notável de resistência por parte dos livres e pobres contra o que aparentemente era uma manobra envolvente do sistema nascente que dava os seus primeiros passos com o registro e contabilidade dos recursos humanos disponiveis para a produção na nova fase. Significava também uma defesa indireta da ordem anterior, o escravismo, na medida em que sua vigência tinha poupado o homem livre e pobre da sujeição completa ao trabalho nas plantations. Enquanto houvesse escravos, o homem pobre continuaria sendo pobre, mas livre. ${ }^{10}$

A mudança do sistema, pelo contrário, levava à superação dessa diferença: homens livres e pobres e escravos seriam progressivamente igualados -não mais pela sua condição jurídico-estamental, mas pela sua pobreza; o processo de ajuste das estruturas sociais e econômicas que adaptava o Brasil às novas demandas do mercado mundial os metamorfoseava assim de homens pobres e livres em apenas homens pobres. Como convinha, aliás, aos critérios do novo sistema social que reorganizava a produção. Nesse sentido, pois, a "Guerra dos Maribondos" foi também uma revolta contra a extinção do escravismo. Uma revolta de indivíduos desclassificados, mas livres.

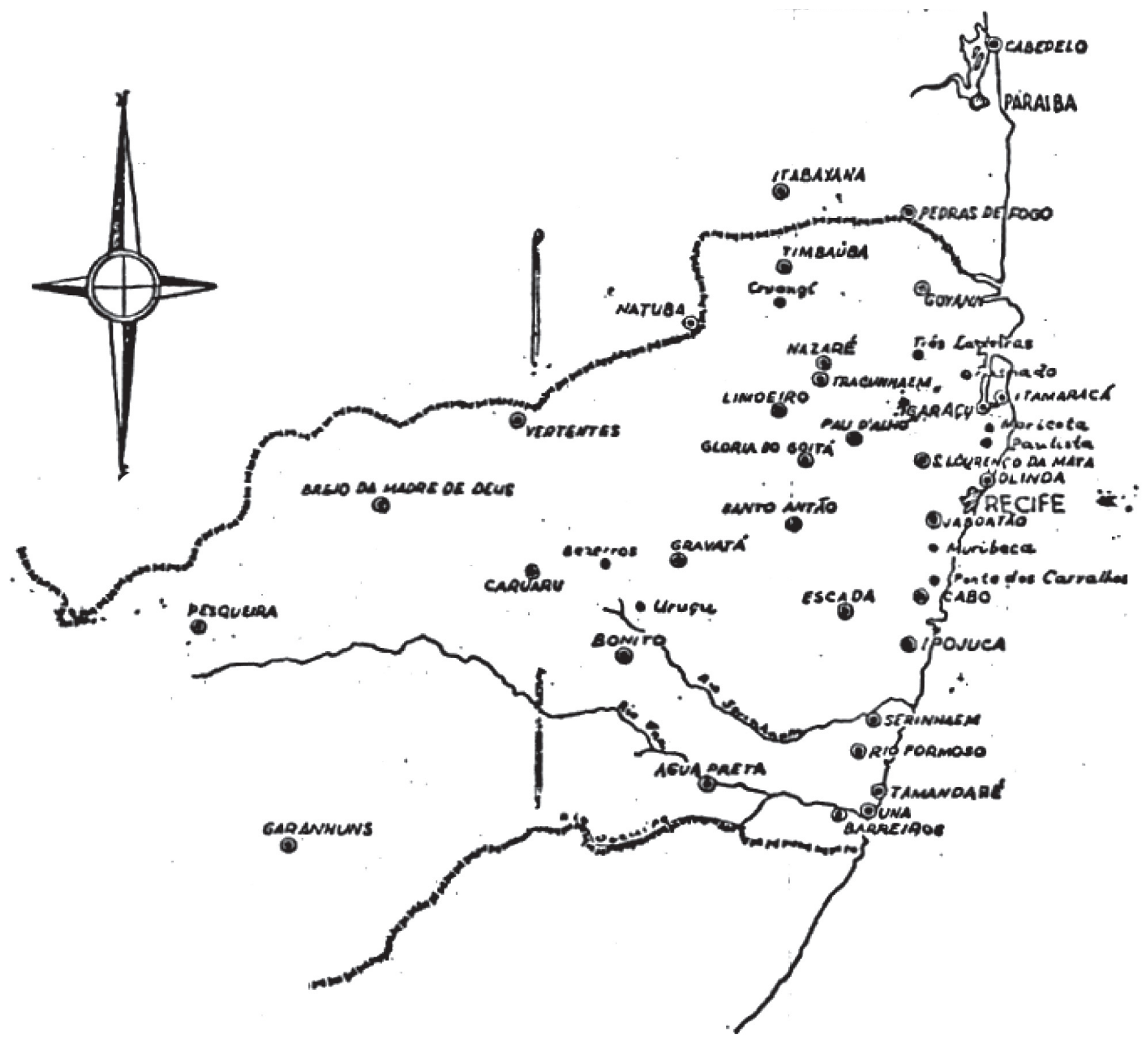


11

Relatório [...] do [...] Ministro dos Negócios do Império, 1850, pp. 36-7.

\section{A 'guerra dos maribondos' em Pernambuco: a transmissão dos fatos.}

Em março de 1850, no seu Relatório à Assembléia Geral Legislativa, o Visconde de Mont'Alegre, então Ministro e Secretário de Estado dos Negócios do Império, queixava-se da precariedade dos dados disponiveis sobre casamentos, batizados e óbitos no Brasil, afirmando:

"[...] além do Municipio da Côrte figuram apenas quatro Provincias, e ainda assim so de duas dessas, Espirito Santo e Maranhão, vieram relações detalhadas. He nesta parte imperdoável o desleixo da mór parte dos Parochos e para pôr termo a semelhante escandalo muito conviria que huma lei thes impuzesse a obrigação de apresentarem todos os anos dentro de hum prazo razoavel a relação dos baptismos, casamentos e Óbitos do anno anterior, não se Ihes pagando jamais a respectiva congrua sem que provem ter satisfeito aquella obrigação: esta simples medida talvez baste para que se obtenha, ao menos este dado estatistico com regularidade e exactidão."11

Esta relativamente pequena pendência entre o Ministro e os párocos ou, se se quer, entre o Estado e a Igreja, deu como resultado o parágrafo $3^{\circ}$ do Art. 17 da Lei $n^{\circ} 586$ de setembro de 1850 que, dispondo sobre 0 orçamento do Império, autorizava o governo a realizar os gastos necessários para elaborar, província por província, o Censo Geral do Império e estabelecer, paralelamente, 'registros regulares de nascimentos e óbitos anuaes'.12 Finalmente, a 18 de junho de 1851, eram expedidos dois decretos - $n^{\circ} 797$ e 798- que mandavam executar ambas as medidas. ${ }^{13}$

Quase seis meses após a promulgação dos decretos, a 19 de dezembro de 1851, um punhado de habitantes da povoação de Rozário de Cima, termo de Pau d'Alho, no limite entre a Zona da Mata Norte e o agreste pernambucano, protagonizava os primeiros protestos contra a aplicação do Regulamento do Registro de Nascimentos e Óbitos, rasgando os editais afixados pelo Juiz de Paz, e exibindo-se armados "[...] para obstarem outro edital, que dizem se ha de fixar [...]"14 Simultaneamente, o Juiz de Paz de Vitória de Santo Antão advertia ao Presidente da Província sobre o crescimento da agitação no campo, sobretudo no meio do "povo mais meúdo", subitamente tomado, dizia o juiz, por "idéias bastante anárchicas e sem que se possa asseverar a V.Excia. que alguem tenha disseminado estas idéias no espirito das pessoas incautas." 15 Aparentemente surpreendido tanto pela rapidez do movimento quanto pela sua natureza, o governo provincial adotou como primeira medida instruir o Juiz de Direito de Vitória -um centro comercial e produtivo de grande importância para o abastecimento da capital da Província- no sentido de que fosse organizada uma força de 200 cidadãos da localidade para enfrentar os distúrbios. A revolta, no entanto, generalizou-se rapidamente na região enquanto o magistrado mostrava-se incapaz de constituir a milícia civil por falta absoluta de voluntários: "[...] esta gente compactua com os sublevados de outras comarcas contra o Decreto de 18 de junho de 1851 [...]." Para agravar a situação, o subdelegado do Termo percorria seu território fazendo recrutamentos para a Guarda Nacional, o que -no dizer do próprio Juiz- contribuía enormemente para acirrar os ânimos das comunidades camponesas da região. ${ }^{16}$ Nesses primeiros dias, a revolta arrastava-se rapidamente pelas comarcas de Vitória de Santo Antão, Pau d'Alho e Limoeiro, enquanto que naqueles lugares onde, a diferença de Vitória, as autoridades conseguiam recrutar e armar voluntários para 
17

Ibid. a ibid, mesma data.

18

Presidente da Provincia a Bispo Diocesano. Recife, 24.12.1851, em DP, 03.01.1852.

19

0 documento acusa igualmente alguns párocos de colaborar, ativamente, ou por omissão, na disseminação da revolta, "imaginando ou fantasiando prejuizos que da execução do Decreto Ihes devem resultar". Presidente da Provincia a Juizes de Direito das Comarcas. Circular. Loc. cit., mesma data. controlar o descontentamento popular, o tiro saia, literalmente, pela culatra: os grupos assim apetrechados, ao invés de dissolverem os contingentes de revoltosos, juntavam-se a eles e engrossavam as filas da insurreição. ${ }^{17}$

Foi em Vitória, aparentemente, no decorrer dos primeiros distúrbios, que a revolta começou a ganhar o que seria posteriormente a sua verdadeira força ideológica. Ali, de acordo com informações do Juiz de Direito, "[...] os individuos mais incautos tem chegado a acreditar que o fim de semelhante Decreto é captivar os homens de côr [...]". Sintomaticamente, foi a motivação assim estruturada da revolta, mais que o número ou a natureza das ações dos sublevados, o que definitivamente espalhou o alarme entre as autoridades pernambucanas, tanto no nivel local quanto no provincial. Nos dias que se seguiram ao 21 de dezembro de 1851, choveram comunicações de juizes e delegados dos mais diversos municípios do interior de Pernambuco, e alguns do próprio Termo da capital, dando conta da formação de numerosos grupos armados, destruição de editais, e enxurradas de ameaças a juízes e escrivões de Paz (os encarregados de aplicar o Regulamento, elaborando o Registro). Todas as alarmadas notícias enfatizavam o fato de que a insurreição se avolumava fundamentada no "boato" do iminente cativeiro dos homens livres e pobres em geral, e já não somente dos "homens de côr".

A segunda medida do governo provincial foi atacar com pesadas armas ideológicas a rebelião, cujo estonteante crescimento fazia que as autoridades tivessem certeza de que tal "boato" se originava, na realidade, na ação subversiva de agitadores profissionais. E enquanto continuava despachando instruções para a formação das milícias cidadãs, o governo provincial apelou para uma poderosa força auxiliar: a Igreja Católica. Assim, nas vésperas do natal de 1851 (o Decreto devia ser lido, i.e., efetivado, nas missas de Natal e Ano Novo), o Presidente da Província alertou o bispo diocesano para o fato de que:

"[...] pessoas mal intencionadas abusando da credulidade da população menos sensata, espalham por alguns lugares do interior da Província ideias falsas a perigosas contra a execução do Decreto de 18 de junho deste anno [...] podendo-se supor que alguns parochos tenham sido indiferentes a essa disposição hostil ao mesmo decreto [...]".18

Na mesma data, em circular dirigida a todos os Juízes de Direito, o Presidente repetia a suspeita de infiltração no movimento popular, contraargumentando que o Decreto, longe de atentar contra "a liberdade dos povos", a consolidava, visto que:

"[...] as bem entendidas disposições do mesmo decreto, já regulando o registro dos nascimentos das pessoas livres e dos escravos [...] acautelam e garantem os sagrados direitos de liberdade, de familia e de propriedade [...]."19

A interpretação politico-partidária do movimento espalhava-se com a mesma rapidez que a própria revolta, e a velocidade de difusão dessa leitura particular dos fatos fazia com que passassem despercebidas diversas informações vindas de alguns pontos do interior que enfatizavam, pelo contrário, a total espontaneidade da insurreição e a marcante ausência de líderes entre os revoltosos. Porém, firmes na sua convicção, os altos escaIões da administração provincial sedimentavam cada vez mais a hipótese, ou melhor, a versão supostamente objetiva e concreta de que a revolta 
20

Secretário de Policia aos Delegados da Provincia. Circular. 31.12.1852, em DP, 12.02.1852.

21

JD de Santo Antão a Presidente da Provincia, 02.01.1852, in MSS JD, 10, v. 1, 1852; Delegado do Termo de Nazareth a Secretário da Policia, 11.01.1852, in DP, 28.02.1852; JD do Limoeiro a Presidente da Provincia, 18.01.1852, em MSS JD, 10, v.1, 1852

\section{2}

Juiz Municipal (doravante JM) do Bonito a Presidente da Provincia, 27.12.1851, em MSS JM v. 7, 1851.

23

Tenente Comandante do $4^{\circ}$ Batalhão de Artilharia a Pé a Secretário da Policia, 31.12.1851, in $D P_{1} 13.02 .1852$.

24

JD de Santo Antão a Presidente da Provincia, s/ d [janeiro de 1852], em MSS JD, vol. cit.

25

Delegado Suplente de Pau d'Alho a Secretário da Policia, 01.01.1852, em DP, 13.02.1852. contra o Registro dos Nascimentos e Óbitos nada mais era do que uma perversa combinação de agitadores e massa ignorante, amalgamada com as temíveis "idéias falsas". Nos últimos dias do ano de graça de 1851, conforme a "Guerra dos Maribondos" alcançava já os principais centros produtores de açúcar da Zona da Mata, o governo pernambucano adotou uma estratégia com duas vertentes: isolar os pretensos "agitadores", identificando-os e prendendo-os, e combater o efeito de suas ações por meio de táticas de dissuasão e apaziguamento dirigidas à população sublevada. 20

Porém, independentemente da cautela na adoção de medidas repressivas, os pedidos de reforços armados, vindos do interior, sucediam-se sem parar, mostrando o claro despreparo dos efetivos policiais dos municipios para conterem a crescente onda de descontentamento popular. Sem saídas visíveis, o governo provincial cogitava já no envio de tropas da Guarda Nacional aos principais centros da conflagração. Uma medida, aliás, fortemente desaconselhada por magistrados e delegados municipais, temerosos de que esse contingente armado, composto em sua maioria de membros de familias de agricultores autônomos, fosse resultar mais numa injeção de efetivos nas fileiras da revolta do que numa forma apropriada de combaté-la. ${ }^{21}$

A situação complicava-se, por outro lado, porque além do crescimento incessante do número de envolvidos na revolta, e do território cada vez mais amplo pelo qual se espalhavam os distúrbios, estes começavam a afetar não apenas regiões e comunidades camponesas e de outras classes de livres e pobres, mas inclusive, agora, "pessoas de diferente condição".22 No último dia do ano ocorreram as primeiras mortes: no meio da agitação na Freguesia de Tracunhaem, municipio de Nazareth, na zona da mata norte, um homem foi morto e seis ficaram feridos. ${ }^{23} \mathrm{~A}$ data fatídica para a aplicação do Regulamento, 31 de dezembro de 1851, transcorreu - tanto nas áreas afetadas pela insurreição quanto na capital provincial - no meio de forte tensão. Praticamente todas as missas de fim do ano rezadas em Pernambuco, sobretudo aquelas da Zona da Mata e do Agreste, foram acompanhadas por grupos de livres e pobres armados, que intimidaram as autoridades civis e eclesiásticas e impediram, com sua presença, sua disposição e suas armas, a apresentação e leitura do Decreto e, em conseqüência, o inicio da sua vigência legal. Mas nem em todos os casos a presença armada foi suficiente: o Juiz de Paz da Escada, $2^{\circ}$ Distrito da freguesia de Vitória de Santo Antão, teve de ser morto para evitar que declarasse iniciada a aplicação do Regulamento, enquanto seu colega da povoação de Miringaba tinha de desistir do mesmo propósito depois de dois atentados a bala contra a sua pessoa. ${ }^{24} \mathrm{Na}$ vila de Pau d'Alho, já convertida no foco principalíssimo da revolta, gritos de "viva a liberdade" proferidos pelos assistentes e por grupos que ocupavam as casas vizinhas à igreja principal celebraram o fim da missa sem que tivesse acontecido a leitura do Decreto, e essa manifestação converteu-se rapidamente no fundamento de uma versão política mais concreta para explicar os acontecimentos. De fato, no mesmo comunicado que participava do sucedido, o delegado suplente informava discretamente ao Chefe da Policia: "[...] temse divulgado que alguns influentes do partido decahido desta comarca tem indisposto o povo [...]".25

A passagem do ano sem que tivesse sido possível praticar o ritual que colocava em funcionamento o Registro do Nascimentos e Óbitos não arrefeceu o ímpeto da revolta. Pelo contrário, animados pelo triunfo obtido, 
Delegado Suplente do $2^{\circ}$ Distrito da Freguesia de Jaboatão a Secretário da Policia, dat. cit., op. cit.

\section{7}

Secretário de Policia a Delegado do $2^{\circ}$ Distrito do Termo da Capital (Jaboatão), loc. cit.

\section{8}

Delegado Suplente de Pau d'Alho a Secretário da Policia, 02.01.1852; Secretário da Policia a Presidente da Provincia,. mesma data, em DP, 16.02.1852.

\section{9}

Documento dos revoltosos ao Delegado Suplente de Pau d'Alho, 02.01.1852, op. cit. Cursivas minhas.

\section{0}

Eisenberg, The Sugar Industry, pp.134-137.

31

Inspetor de Indios da Freguesia da Escada ao Subdelegado do $1^{\circ}$ Distrito da Escada, 02.01.1852; Subdelegado do $1^{\circ}$ Distrito da Escada a Secretário da Policia. Figueira de Melo, por sua vez, resumiu -ou melhor, reduziu- as informações anteriores comunicando ao Presidente da Província que tudo não passava de agitações dos 'anarchistas da Freguesia da Escada'. Secretário da Policia a Presidente da Provincia, 03.01.1852. Cf. DP, 17.02.1852. os livres e pobres avançaram as fronteiras do seu movimento. Assim, em $1^{\circ}$ de Janeiro a insurreição aproximava-se já dos subúrbios do Recife e 400 homens armados ocupavam a sede da freguesia de Jaboatão, dispostos a impedir a tudo custo a leitura do Decreto. ${ }^{26}$ Isto para desespero do Secretário da Policia, que disparava insistentes instruções a seus homens no sentido de que mostrassem aos revoltosos que o Registro não visava "destruir a liberdade, mas pelo contrário a garanti-la, fazendo com que se multipliquem mais os títulos, pelos quais se prova que alguem nasceu livre". 27 Em Pau d'Alho, por último, indícios que poderiam servir para uma interpretação política da revolta dos livres e pobres aumentavam com a visita de um grupo de "200 homens pardos, pretos e cabras" ao Delegado Suplente da vila, quem informava que "entre suas vociferações aparecem os gritos "morram os guabirús; morram os caiados", enquanto mais de 400 homens da mesma qualidade - declarava o policial - tinham protagonizado atos semelhantes na vizinha freguezia da Glória. Para o Delegado a situação já era bem outra, muito distante de uma simples oposição ao Registro, e longe igualmente da mera infiltração de agentes subversivos no movimento popular. Havia causas mais profundas:

"[...] Bem parece que esta sublevação he de propósito contra a lei dos nascimentos e Óbitos porque esta foi estipulada por uma assembleia que Ihes he desafecta [...]."28

No entanto, os pretos, pardos e cabras que tinham visitado o Delegado não manifestaram, na ocasião, nenhum sentido político nas suas reivindicações, mostrando, pelo contrário, uma clara e direta preocupação social, quase doméstica, como a condutora do seu movimento. Desse grupo é o único documento escrito, apresentado pelos sublevados, que se conserva, e diz o seguinte:

"Tendo nós, pretos e pardos pobres, noticia do papel da escravidão que hoje era o competente dia de se ler, desejamos saber de V.S., como autoridade superior encarregada, se he ou não verdade [...) Também temos noticia que os escrivães dos juizes de paz, de hoje em diante, são uns dos encarregados respectivos aos baptisados, sem certidão delles não se poderá fazer uma criança christã ; e como o povo todo em massa não quer essa lei pouco dura, ou então V.S. vera todo o povo desgraçado, ficando V.Sa. obrigado a tudo isso."29

Mas foi da Escada de onde começaram a chegar alarmantes notícias de que as pessoas "mal intencionadas" e os "anarchistas" dos primeiros dias dos distúrbios estavam agora transfigurando-se em praieiros de carne e osso. De fato, o Inspetor de Índios da freguesia -um dos focos centrais da insurreição praieira-, ${ }^{30}$ após confirmar que na povoação se repetiam os mesmos distúrbios acontecidos no resto das áreas conflagradas, apontava o agravante de que entre os protagonistas da revolta local se destacavam "11 homens armados, a mor parte indios ou alistados como isso, moradores do segundo districto no Engenho Cassera junto aos Srs. Afonso". E advertia ao subdelegado: "Você deve tomar todas as providências, pois a outra revolução assim principiou."31 Porém, se as autoridades perdiam-se por diversos caminhos no seu propósito de entender o que estava acontecendo com os "pacatos" homens livres e pobres, estes também avançavam na explicação das causas de seu movimento. Muribeca, outra freguesia da periferia do Recife, foi igualmente invadida nos primeiros dias do ano "por 
32

Subdelegado de Muribeca a Secretário da Polícia, 02.01.1852, em loc. cit.

33

Delegado do Termo de Iguaracú a Secretário de Policia, 03.01.1852, em DP, 18.02.1852. Cursivas minhas.

Subdelegado de Nazareth a Secretário de Policia, 04.01.1852, in DP, 04.03.1852. grande numero de pessoas armadas [...] com o pretexto de não consentirem na leitura de um tal papel que segundo dizem elles tem por fim reduzir à escravidão as crianças que nascerem do primeiro do corrente ano em diante." 32 No dia 4 de janeiro de 1852, Figueira de Mello, cada vez mais convencido não só das origens "praieiras" do movimento, como da impossibilidade de solucionar o conflito por vias persuasórias, participava ao Presidente da Província do surgimento de mais um foco de agitação: o importante centro açucareiro de Iguaraçú, imediatamente ao norte da capital -cada vez mais cercada-, e solicitava reforços urgentes para seu destacamento e os das ameaçadas vilas de Santo Antão, Pau d'Alho, Nazareth, Goiana, Serinhaem e Rio Formoso, as três últimas, como Iguaraçú, grandes produtoras da riqueza açucareira regional. Comunicava também que a revolta nutria-se agora de boatos muito mais abrangentes do que os originários, que não falavam mais em simples ameaças, nem focalizavam prioritariamente os "homens de côr", nem sequer concentravam o âmbito da revolta no Registro. Espalhava-se agora pelos canaviais, pelos campos de mandioca, pelos plantios de algodão, pelas roças e pelos coqueirais a noticia de que se tentava "[...] escravisar os homens livres e pobres pelas novas leis da Guarda Nacional e registro dos nascimentos e óbitos [...]."33

Enquanto isso acontecia em torno ao Recife, o crescimento da violência e o recrudescimento da agitação em Pau d'Alho provocavam temores de marchas de contingentes de livres e pobres sublevados sobre aqueles municípios e vilas das proximidades ainda não tomados pela revolta. Em Nazareth, o Delegado finalmente tinha conseguido reunir 300 homens armados para enfrentar grupos de insurretos que teriam saido de Pau d'Alho para ocupar a vila. Mas as coisas estavam claramente chegando a niveis intoleráveis para a estrutura da ordem na Província. Os sobressaltos provocados pelo movimento dos livres e pobres começaram a propiciar tímidos, porém significativos, ensaios de reunificação das lideranças liberais e conservadoras, as mesmas que três anos antes tinham comandado - antagônicamente - suas forças em batalhas sem quartel durante as sangrentas jornadas da insurreição praieira. Em Nazareth, sitiada pelo medo da sublevação das "classes mais baixas", os membros de ambos os partidos políticos que lutavam pelo poder juntaram-se rapidamente para enfrentar o povo armado, desmentindo as generalizações partidárias feitas pelo Chefe da Policia (que nem por isso parou de insistir na sua versão) e as particularidades elaboradas pelas autoridades de Escada. No comando de liberais e conservadores, unidos numa mesma causa, o Subdelegado de Nazareth garantia ao seu chefe na capital que:

"[...] nenhuns fundamentos haviam para se crer que o partido da oposição tivesse parte na amotinação popular; a vista disto estabeleceuse aliança entre os chefes mais eminentes de ambos os partidos politicos desta cidade afim de garantir-se a paz pública [....]."34

A providencial aliança entre os cidadãos 'políticos', entre os descendentes dos antigos homens bons, pertencentes a partidos políticos formalmente opostos e por vezes - de maneira igualmente formal - irreconciliáveis, para lutar contra a ingerência de grupos subalternos, como os sublevados, em questões que, segundo todas as opiniões avalizadas, não Ihes diziam a respeito, incluía também juramentos de fidelidade por parte de distintos ex-praieiros e promessas textuais de virarem informantes do governo conservador da Província com relação a qualquer envolvimento 
Presidente da Provincia a Bispo Diocesano, 24.12.1851, em DP, 03.01.1852; idem a JD das Comarcas, 'Circular', mesma data, loc. cit.; JD de Santo Antão a Presidente da Provincia, s/d (dezembro de 1851), vol. cit.; Secretário da Policia a Delegado do $2^{\circ}$ Distrito da Capital, 01.01.1852, em DP, 13.02.1852; Idem a Presidente da Provincia, 15.01.1852, em DP, 17.03.1852, 'Publicações a pedido', etc. Vid. também os comentários sobre o comportamento dos párocos mineiros, que se diziam ofendidos pela 'dependência dos escrivães de paz nos actos do seu Ministério', em ibid, 25.02.1852, 'Interior. Minas Gerais. Ouro Preto, 2 de janeiro de 1852 '; Cf. igualmente as mordazes e divertidas crónicas do correspondente do DP na Paraiba, onde 'Os vigários e padres andam pelo mato muito assustados com o povo por causa do censo [...] Alguns dos reverendissimos tem também de sua parte açulado ao povo, dislembrando de que seu ardente zebo Ihes pode ser muito fatal', em ibid., 07.02.1852, 'Correspondência do Diário de Pernambuco na Parahyba'.

37

Presidente da Provincia a Juizes de Paz. 'Circular', 02.01.1852, in DP, 08.01.1852; Bispo Diocesano aos Párochos das Freguezias da Provincia. 'Circular', 01.01.1852, loc. cit.; o correspondente do DP na Paraiba declarava: 'nada mais opresivo do que vedar a sepultura eclesiastica de um cadaver, que como se sabe não pede licença para feder'. DP, 10.02.1852, 'Correspondência do Diário de Pernambuco. Parahyba, 6 de fevereiro de 1852'. do Partido Liberal ou de membros deste na revolta popular. No entanto, a disponibilidade dos liberais não foi suficiente, e a força bipartidária de Nazareth ficou imobilizada enquanto se discutiam as garantias da efetividade da aliança entre os até muito recentemente inimigos mortais. A interpretação partidária do movimento tornava-se assim uma faca de dois gumes, e, nessa guerra de boatos, foi um boato mais o que resolveu o impasse: a revolta era política e conforme informação oferecida por um homem da "oposição" local, Nazareth estava na iminência de ser atacada por uma forte coluna armada de homens livres e pobres chefiada por um comandante liberal: [...] Desde então tudo foi confuzão [...] em menos de 10 minutos ficou a cidade evacuada pela força, e por muitos dos seus habitantes, ficando apenas comigo o destacamento de linha e mais 6 ou 8 pessoas do povo [...].35

Do lado da Igreja Católica, já envolvida diretamente no conflito tanto pelas próprias raizes dos protestos quanto pelas urgentes solicitações -de fato intimações- formais de colaboração no seu apaziguamento emitidas pelo governo provincial, as coisas não pareciam estar melhor. Muito pelo contrário. Os párocos já haviam sido criticados - veladamente primeiro, de maneira aberta depois - pelas autoridades civis da província por causa do seu comportamento indiferente, sua omissão no desarmamento do espírito dos seus rebanhos e pela sua participação por vezes ativa no acirramento dos ânimos - com o que julgavam contribuir à defesa das suas próprias prerrogativas de continuarem monopolizando o rendoso negócio de batizarem os vivos e encomendarem os mortos. ${ }^{36}$ Agora aproveitaram falhas administrativas para aprofundar o enfrentamento com a determinação imperial. Foram vários os casos de sacerdotes que negaram-se a praticar os ritos correspondentes ao batismo ou aos óbitos, por não estarem os interessados munidos das guias que o Regulamento do Registro mandava que deviam acompanhar nascidos e defuntos. A burocracia imperial esquecerase de fazer coincidir a aplicação do Regulamento com a feitura das guias, e de um dia para o outro, começaram a se acumular nascidos sem batismo e mortos sem sepultura em dezenas de municípios pernambucanos, enquanto párocos e escrivões de paz declaravam-se impossibilitados de cumprir com as suas novas funções.

Diante de fatos tão macabramente concretos ocorreu a segunda capitulação do governo provincial na "Guerra dos Maribondos". 0 dia 2 de janeiro de 1852 (dois dias antes de Figueira de Mello decidir que o movimento era definitivamente uma manobra praieira) o Presidente da Província ordenou a todos os Juizes de Paz de Pernambuco que ignorassem as disposições do Regulamento e permitissem a normalização burocrática do ritmo de vida e morte dos livres e pobres. Simultaneamente, o bispo diocesano deu instruções similares aos párocos, "declarando-Ihes que devem continuar a administrar o baptismo e dar sepultura aos mortos da mesma forma que até o presente". E, mais importante, diante do terrivel descrédito dos seus vigários, o bispo decidiu também que era chegada a hora de chamar à ação o imaculado poder de conversão dos homens santos, e mandou o prefeito dos Capuchinhos de Pernambuco, frei Caetano de Messina, "pacificar" os principais focos da revolta. 37 Porém, enquanto o governo e a Igreja recuavam diante do ímpeto da sublevação, que já ocupava quase a totalidade dos principais centros produtivos da província, uma nova força entrava no cenário, o famoso quarto poder. De fato, o Diário de Pernambuco, finalmente sensibilizado pelo alarme que já corria solto pela próprias ruas 
38

$D P, 06.01 .1852$.

39

JD de Santo Antão a Presidente da Provincia, 06.01.1852, in MSS JD, vol. cit. Cursivas minhas. da capital provincial, publicava na primeira página da sua edição de 6 de janeiro de 1852 o seguinte aviso:

"Como de ontem para cá se tenham espalhado nesta cidade boatos aterradores, dizendo uns que tudo o centro da Província se acha em chamas e acrescentando outros que até em vários lugares já tem corrido o sangue brasileiro, damo-nos pressa em [desmentir) [...] tendo havido apenas na [comarca] de Pau d'Alho uma amotinação sem derramamento de sangue, causada pela falsa e deplorável opinião que formou o povo d'alli contra o decreto de 18 de junho [...]."38

0 governo provincial, ou melhor, a Secretaria de Policia, - já inteiramente absorvida pela insurreição - não descuidava contudo de suas discretas tarefas de investigação das fortes suspeitas de ação subversiva no bojo do movimento popular. Mas as hipóteses nesse sentido continuavam defrontando-se com fatos pouco animadores. 0 juiz de Vitória, enviado pelo presidente da província a comprovar as acusações provenientes de Escada, não conseguiu arrolar quaisquer tipo de provas da atuação dos 'anarchistas' denunciados pelo Inspetor de Índios. Limitou sua secreta missão apenas a 'infiltrar-se' numa reunião de 50 senhores de engenho, com tão pouco sucesso -ou com tanta cumplicidade- que, apesar de ter estado presente às discussões, saiu dela dizendo ter sido uma reunião "cujo fim ignoro qual seja". Porém, informações preciosas - para o presente estudo - viriam dessa aparentemente frustrante visita do juiz, como a seguinte declaração:

"[...] o motivo pelo qual o pôvo se ostenta tão descontente e ameaçador, he porque diz que as disposições do Decreto tem por fim captivar seus filhos, visto que os Inglezes não deixam mais entrar Africanos [...]."39

Por volta do dia 7 de janeiro, frei Caetano de Messina, prefeito do Hospício dos Capuchinhos da Igreja da Nossa Senhora da Penha em Recife, chegou finalmente à vila de Pau d'Alho para iniciar a "pacificação" dos insurretos, e foi recebido, segundo alguns observadores, com "sinais do mais intenso jubilo" da parte dos amotinados. Mas a sua chegada, paradoxalmente, marcou também um dos momentos mais graves do confronto entre os livres e pobres e o aparelho do Estado. Aparentemente sem o saber, o frade estava sendo a vanguarda involuntária de nada menos que o $9^{\circ}$ Batalhão de Infantaria, enviado pelo governo provincial, o qual foi emboscado e atacado pelos sublevados, vendo-se forçado a recuar após intensa fuzilaria com dois mortos e cinco feridos, enquanto os destacamentos de revoltosos recolhiam-se de novo a Pau d'Alho. Curiosamente, a tarefa de "pacificação"que tinha levado o santo frade a essas paragens teve de começar não pelos insurretos e sim pelas próprias tropas do governo. De fato, foi necessária uma severa intervenção de frei Caetano para evitar que o $9^{\circ}$ Batalhão, ferido nos seus brios, tomasse a sangue e fogo a vila, e longas e pacientes conversas com seu comandante para convencé-lo a postar seus soldados a uma prudente distância do núcleo urbano, dando tempo para que se acalmassem os ânimos. 40

Enquanto a tensão acumulada levava ao confronto armado entre contingentes avançados dos livres e pobres e tropas de linha do governo, e enquanto os chefes políticos de Nazareth se desentendiam e o juiz de Vitória de Santo Antão voltava a sua sede tendo participado da reunião referida sem ter encontrado vestígios do envolvimento de ex praieiros na revolta, eis que dois proeminentes chefes da Revolução de 1848, Jerónimo 
41

Ambas as declarações em DP, 09.01.1852. 'Correspondências'
42

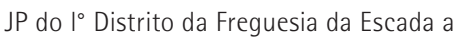
Presidente da Provincia, 10.01.1852, in MSS JP, V. 12, 1850-1852. 0 Juiz era Manoel Jorge Pereira Lima, membro de uma abastada família de senhores de engenho.

43

Subdelegado a Delegado do Termo de Goiana, 06.01.1852; Delegado de Goiana a Delegado da Policia, mesma data, em DP 20.02.1852.

\section{4}

JM Suplente de Iguaraçú a Secretário de Policia, 07.01.1852, loc. cit. 0 Juiz insiste em atribuir o movimento 'a suggestão d'aquelles mesmos desordeiros, que adquiriram triste celebridade nas sedições passadas'
Vilela de Castro Tavares e Ignacio Bento de Loyola, vieram a público para manifestar, entre outras coisas, seu inteiro desacordo com o movimento popular, nos seguintes e claros temos proferidos por Castro Tavares:

"Tendo infelizmente aparecido em alguns pontos da província movimentos sediciosos, motivados pela execução da lei de registro de nascimentos e óbitos, e podendo alguém prevalecer-se da ocasião para faze-rme quaisquer imputações e atribuir-me fatos criminosos, apresso-me em declarar pela maneira mais solene e positiva, que nem direta, nem indiretamente tenho parte alguma nesses movimentos; que alta e poderosamente os reprovo como opostos à civilização e como um meio infalivel de retardar a marcha e o progresso do partido liberal, a que me prazo de pertencer. Tenho a mais profunda convição de que nenhum membro notável do Partido Liberal se ha envolvido nesses acontecimentos".

Bento Loyola não era menos enfático e oferecia-se inclusive para lutar, lado a lado com os conservadores, contra a rebelião:

"[...] declaro perante Deus e os homens que não só desaprovo os desvarios e loucuras desses fascinados homens que se rebellaram contra a execução das leis do paiz, mas que desde já hypoteco os meus serviços ao governo para ajudá-lo na manutenção da paz."41

Na Escada, contudo, a versão politica do movimento continuava campeando solta e gerando denúncias e paranóias de alguns funcionários públicos, apesar das tranqüilizantes opiniões do juiz de Vitória. Uma semana após a primeira declaração do Inspetor de Índios, o Juiz de Paz do $I^{\circ}$ Distrito da freguesia repetia mais ou menos os mesmos conceitos do encarregado do aldeamento, referindo-se à ação dos 'anarchistas constituintes' (praieiros), que espalhavam boatos sobre o iminente cativeiro da "gente baixa". Não eram só os próprios membros do Partido Liberal da localidade a fazerem esse tipo de propaganda - continuava o juiz - , mas também, por encomenda, seus moradores e agregados. E a tal reunião de senhores de engenho que tinha deixado o juiz de Vitória casualmente ignorante de tudo, teria tido na realidade a função de criar uma Sociedade Constituinte, "a qual tem dado todo incremento e ouzadia à plebe; que apezar de não toda ser meramente crédula, com tudo segue a seus prozelitos como maiores". E concluía: "acha-se a classe baixa desta freguezia em tal atitude de exaltação que não respeitão as autoridades e nem o direito de propriedade".42

No fim da primeira semana de Janeiro a revolta entrou na sua fase mais aguda quando começaram a dar-se assaltos a casas grandes de engenhos e propriedades abastadas nos municípios atingidos pela revolta, sobretudo naqueles situados na região açucareira da Mata Norte. No dia 6 de Janeiro foi a vez da velha cidade de Goiana dar o alarme diante do ataque ao engenho Gutiubá de "uma porção de proletários instigados", propriedade do subdelegado de Policia Antonio de Araujo e Albuquerque, que conseguiu fugir. Provocou com isso a fúria dos invasores, que assaltaram a mulher, mataram um negro forro e "a cria Joaquina", e deram tremenda facada no mestre de açúcar. ${ }^{43} \mathrm{Em}$ Iguaraçú aconteceram também diversos ataques a grandes propriedades rurais, acompanhados de extorsões praticadas pelos insurretos, que obrigavam os proprietários a entregar, além de ouro, prata, jóias e objetos de valor, armas de fogo, munições e comida, "a que tudo tem dado lugar a retirada da maior parte dos proprietários e o escondimento de suas famílias nas matas". 44 Em conseqüência desses atos, no dia 
45

$D P, 10.01 .1852$.

46

Subdelegado de Panelas a Secretário da Policia, 06.01.1852; Delegado de Garanhus a idem; Secretário da Policia a Presidente da Provincia, 26.01.1852, em DP, 09.03.1852; idem a idem, s/d., em ibid, 25.02.1852. As principais localidades afetadas eram Panelas, Buique, Papacaça e Aguas Belas, todas no Termo de Garanhuns, e no Distrito das Varas, Termo de Flores.

\section{7}

Para depoimentos aproximadamente contemporâneos da importância comercial do Limoeiro, veja-se Koster, H., Viagens ao Nordeste do Brasil. Recife, Secretaria de Educação e Cultura, 2a ed., 1978. p.354; Tollenare, L.F. Notas Dominicais. Recife, Secretania de Educação e Cultura, 1978. p88.

\section{8}

JD do Limoeiro a Presidente da Provincia, 05.01.1852 e 11.01.1852, in MSS JD, vol. cit.

49

Ibid. a lbid., 11.01.1852 e 23.01.1852, em MSS Policia Civil, 40, 1852.
7 de janeiro o Presidente da Província tomou a medida extrema de mandar recolher a dependências do governo todas as armas de fogo, a pólvora e 0 chumbo que se encontravam a venda nos armazéns do Recife e nas lojas dos subúrbios da capital. Entretanto, imperturbável, o Diário de Pernambuco continuava com sua tarefa de 'contra-informação', atribuindo os ataques às propriedades rurais da Zona da Mata Norte a "alguns malvados, que desgraçadamente nunca faltam em taes ocasiões", e afirmando que o resto da província se encontrava na mais completa calma. ${ }^{45} \mathrm{E}$, no entanto, precisamente por aqueles dias a "Guerra dos Maribondos" começava a espalhar-se também pelo agreste e pelo sertão pernambucanos. ${ }^{46}$

Desde o dia 5, 100 livres e pobres armados tinham ocupado a vila do Limoeiro, a mais importante do Agreste meridional por sua natureza de primeiro centro de comercialização do algodão. ${ }^{47}$ Após darem fim aos editais do Decreto afixados pelas autoridades locais, os sublevados deram vivas "ao Imperador, a padroeira, ao vigário, a liberdade e ao povo de Limoeiro"; ato seguido, soltaram os recrutas confinados na cadeia pública e forçaram o Juiz de Direito da Comarca a coletar mantimentos para a tropa, enquanto a força policial fugia mais do que rapidamente. Na continuação ocuparam a cadeia e distribuiram pelotões de guarda nas entradas da vila. No dia 8 já eram mais de 300, nomearam um comandante da força de ocupação e informaram o juiz local que, além das reivindicações básicas contra o Registro de Nascimentos e Óbitos, e contra o recrutamento para a Guarda Nacional, queriam o fim de todos os tributos e a "separação do norte". Logo após começaram a negociar com o juiz a nomeação de um novo delegado, e a discutirem a possibilidade de deporem as armas caso frei Caetano de Messina supervisionasse a operação. Para tanto deram um salvo-conduto ao magistrado, que partiu imediatamente para Pau d'Alho a procura do frade, mas no caminho deu de cara com outro contingente de 150 insurretos comandados por " 3 pessoas brancas, de sentimentos de ordem", que conduziam a tropa, aparentemente sob ameaça de morte. Um "oficio dos três comandantes do povo armado" mandou o juiz de volta para Limoeiro, onde encontrou a forca de ocupação já composta por aproximadamente 500 homens. ${ }^{48}$ Novamente em casa, o magistrado receberia diversas comissões dos ocupantes da vila, "gente paupérrima", exigindo "que Ihes entregasse a Ley que os obrigaria a dar as nomes dos seus filhos ao Escrivão de Paz; dizendo que na dita Ley hé que tinha a ordem do Governo para os captivar". 49

A proibição de venda de armas, chumbo e pólvora foi imediatamente posta em prática no Recife e vizinhanças, mas os senhores de engenho das freguesias onde a sublevação corria solta, e a própria policia provincial, não demoraram em perceber que se tratava de uma medida que tinha também seus inconvenientes, além de uma duvidosa utilidade. De fato, a proibição afetava apenas de maneira relativa o progresso da revolta armada, já que por essas datas os insurretos esvaziavam meticulosamente os nutridos arsenais das casas grandes da Zona da Mata Norte e deixavam os senhores de engenho sem armas para se defenderem, e incapacitados de adquirilas para substituírem as roubadas por causa da determinação do governo. Rapidamente, pois, um grupo de proprietários de engenhos de Iguaraçú, representados pelo Juiz Municipal suplente, Dr. Francisco João Carneiro da Cunha, membro da nata da oligarquia local, entrou com um pedido diante do Secretário da Policia no intuito de excluir da proibição de compra de armamento os senhores de engenho em geral. Figueira de Mello, natural- 
50

Secretário da Policia a Presidente da Provincia, s/d [circa. 10.01.1852]; ibid. a Delegado de Iguaraçú, 12.01.1852, em DP, 25.02.1852

51

DP, 'Retrospecto Semanal', 12.01.1852; Secretário de Policia a Presidente da Provincia, mesma data, loc. cit

52

Secretário de Policia a Delegado Suplente do Termo do Cabo, 13.01.1852, em DP, 27.02.1852. Cursivas minhas. 0 Chefe da Policia fez frequente uso de informantes e agentes secretos durante a revolta.

53

Delegado do Termo de Nazareth a Secretário de Policia, 11.01.1852, in DP, 28.02.1852; Secretário da Policia a Subdelegado do $2^{\circ}$ Distrito de Bom Jardim, 13.01.1852, in ibid., 27.02.1852. mente, apoiou a petição em oficio ao presidente, dando fé de que se tratava de homens "dignos da graça, que pedem, e que o governo terá nelles defensores visto que são cidadãos pacificos, e ostentaram sempre sentimentos de ordem e legalidade". A autorização foi rapidamente concedida e as armas enviadas com presteza aos assustados peticionários. ${ }^{50}$ Nesse mesmíssimo dia, o Diário de Pernambuco lançava mais uma das suas pérolas de desinformação no seu "Retrospecto Semanal", louvando a "imperturbável" calma que prevalecia na província, com a única [sic] exceção da mesma vila de Pau d'Alho, "onde os camponezes ou matutos se amotinaram e lançaram mão das armas". Em outra seção da mesma edição, o jornal trombeteava o fim da revolta com a pacificação completa da irrequieta vila. 51

Como certamente o leitor terá percebido, no cerne da revolta contra o Registro de Nascimentos e Óbitos, outras questões que com toda certeza preocupavam de forma parecida aos agricultores livres e pobres envolvidos no movimento, além - ou ao lado - do mais iminente perigo do seu possível cativeiro para substituírem aos escravos, foram aparecendo conforme a revolta avançava. Protestos contra o recrutamento, contra a ingerência do poder público na vida interna das comunidades camponesas e dos livres e pobres em geral, contra o pagamento de impostos e tributos, etc., surgiam esporádica e ainda tímidamente das mesmas gargantas que exigiam o fim do Registro. Ao mesmo tempo, os "desrespeitos" ao direito de propriedade, tão denunciados pelas autoridades da Escada, alcançavam proporções alarmantes nas freguesias açucareiras da Zona da Mata Norte e, aos poucos, pareciam suscetíveis de enveredarem por outras perigosas direções e atacarem instituições muito mais vitais para a ordem agrária existente na região, e no Império. Um desafio a esse tipo de sustentáculos da estrutura do poder sócio-político aconteceu na freguesia do Cabo, provocando arrepios em proprietários e autoridades, quando um grupo de insurretos, reunidos no primeiro dia do novo ano no oratório do engenho Gaipió para impedirem a leitura do decreto do Registro "chegaram ao arrojo de ameaçarem os Srs. de engenho, que dessem despejo aos seus moradores, como hé costume no legitimo uso de sua propriedade". A informação, obtida de fontes não explicitadas, resultou numa forte reprimenda do Secretário da Policia ao Delegado suplente do Termo, por "não ter dado parte a esta repartição de um tão extraordinário acontecimento que não devia nem podia ignorar". 52

No resto da província, a revolta progredia incorporando novas regiões ao descontentamento popular. Até então relativamente à margem dos distúrbios, a freguesia de Bom Jardim, limitrofe com o Limoeiro, ampliou o mapa da guerra popular no final da primeira quinzena de Janeiro, enquanto a vila de Nazareth caia nas mãos dos revoltosos, que imediatamente fecharam as entradas, não tanto para impedir a comunicação com o minúsculo e inofensivo destacamento policial, quanto para barrar a aparição de novos exemplares do terrivel edital do Registro. 0 destacamento da Guarda Nacional ai postado foi tão inútil quanto o da policia, embora por diferentes motivos: "[...] também está fazendo parte desses anarchistas [...]".53 No vizinho Limoeiro, ocupado desde princípio do mês, continuava o impasse entre autoridades e insurretos, e o delegado titular, de volta às suas funções perdia a paciência e mostrava a Figueira de Mello as cartas que ele, delegado, julgava serem as que estavam no jogo:

"[...] o negôcio, llustrissimo senhor, já não é mais, e nunca foi, sisma do povo por causa da lei do Censo [sic], he o partido praieiro que se apro- 
54

Delegado de Limoeiro a Secretário de Policia, 12.01.1852, em ibid., 02.02.1852.

55

Delegado Suplente do $2^{\circ}$ Distrito do Recife a Secretário da Policia, 13.01.1852, loc. cit. Cursivas minhas.

56

Delegado do Termo de Nazareth a ibid., 11.01.1852, em DP, 28. 01. 1852.

57

JD do Limoeiro a Presidente da Provincia, em MSS JD, vol. cit. Apesar dos seus esforços, e talvez por ter tido durante todo o conflito atitudes conciliatórias - acrescidas, aparentemente, da culpa decorrente de pecados anteriores - o juiz foi acusado de "intima ligação com os inimigos do Govemo" pelo Secretário de Polícia, quando da diatriba deste com o Presidente da Provincia. Cf. Secretário da Policia a Presidente da Provincia, 15.02.1852, in DP, 17.03.1852,

"Publicações a pedido". veita desta lei para dispor as massas à seu favor [...] não se pode calcular o perigo imminente que correm milhares de famílias desta comarca à vista do desenvolvimento de um povo feroz e mal aconselhado [...].".54

A participação e militância multitudinária na revolta continuava, no entanto, sendo predominantemente atribuída às "classes baixas" - com essa ou outras denominações. Mas uma clara simpatia, ou pelo menos uma ativa neutralidade de segmentos da população urbana e rural que não se enquadravam nessas categorias subliminares da sociedade da época, manifestava-se nitidamente em quase todas as vilas e povoações alcançadas pela insurreição como um inesperado e - para os representantes da ordem - irritante complicador da revolta e das tentativas por isolá-la e abrir espaço, assim, para encontrar uma solução pela força. Praticamente em nenhum caso dera resultado a convocação de milícias cidadãs, enquanto que a Guarda Nacional, como vimos, revelava-se muito mais um inimigo potencial e temivel do que um instrumento apropriado para combater uma sublevação popular. Nos próprios subúrbios da capital provincial, apatia, desinteresse e indiferença - por vezes uma velada parcialidade da população pelos rebeldes - eram a tônica. No $2^{\circ}$ Distrito (Jaboatão), por exemplo, dos cidadãos instados a defenderem o governo contra os livres e pobres "[...] nenhum aceitou o convite, talvez pelo espirito fanático que os domina, pois se bem estejam mais capacitados, com tudo qualquer ordem de reunião os torna desconfiados, e sem que haja prisões não se sujeitam [...]".55

No lado oposto, proprietários de terras e senhores de engenho, bem armados e organizados em grupos de repressão e combate à revolta popular, também provavam ser de pouca ajuda para enfrentar as forças dos livres e pobres. Na Nazareth ocupada e cercada pelos insurretos, o delegado tinha conseguido a duras penas reunir e armar um número razoável de proprietários e "paisanos", e com eles propunha-se partir "para a defesa da causa do governo". No entanto, a arma mais eficaz desta guerra peculiar, o boato - desta vez da aproximação de uma força de 400 sublevados - "fez desperçar incontenente [sic] aquelles proprietários, que asseveravam-me defender a causa justa de S.M. o Imperador". 56 Métodos mais práticos e eficientes de combater a revolta, ou pelo menos de frear a sua capacidade de atração de novos grupos de simpatizantes, estavam sendo utilizados em lugares onde o confronto havia estabelecido situações aparentemente sem saída, como no Limoeiro. Ali vários notáveis da vila, impacientes com a duração do impasse e animados por uma espécie de paralisia que tinha acometido a iniciativa das cabeças dos livres e pobres após os primeiros dias da ocupação, acalmavam relativamente os ânimos, sendo que um deles, "oficial de honra e valente [...] teve a habilidade em uma noite de reduzir mais de cem revoltosos a obediência do governo, já com a persuação, e já com dinheiros, que the mandei espalhar [...]".57

Pacificado Pau d'Alho, pelo menos parcialmente, na base da presença nas vizinhanças de fortes corpos de tropa de linha e de solenes e aparatosas cerimônias litúrgicas, acompanhadas de pesadas penitências impostas por frei Caetano a toda a população, sem distinções, o santo frade dirigiu-se a Limoeiro, desta vez plenamente consciente de que o $9^{\circ}$ Batalhão vinha atrás. Porém, sua chegada, tão aguardada por gregos e troianos, teve, entre outras conseqüências, a virtude de fazer patente um outro aspecto da revolta, aparentemente restrito, nesses anos, as regiões agrícolas não açucareiras situadas ao noroeste da Zona da Mata Norte: a penetração de cultos protestantes e, ao que parece, a resistência dos seus seguidores 
Bispo Diocesano de Pernambuco, D. João da Purificação Marques Perdigão, a todos os Diocesanos, em DP, 10.01.1852 (e repetida nos dias 11, 12 e 13 do mesmo mes).

59

JD de Limoeiro a Presidente da Provincia, s/d. em MSS JD, vol. cit.

60

DP, 19.01.1852; Hyginio José Coelho, Comandante do $9^{\circ}$ Batalhão, a Presidente da Provincia, 16.01.1852, anunciando sua entrada, sem novidades, na vila ocupada pelos livres e pobres, em ibid., 20.01.1852

61

Os receios impediram, por exemplo, que diversas freguesias organizassem, como deveriam, as listas eleitorais para pleitos provinciais nesse ano. Cf. JP do $1^{\circ}$ Distrito da Escada a Presidente da Provincia, 20.01.1852; JP do Limoeiro a ibid., 23.01.1852; JP de Glória de Goitá a !bid., 07.06.1852, em MSS JP, v. 12, 1850-1852.

\section{2}

JD de Garanhús a Presidente da Provincia,

26.01.1852, em MSS JD, vol. cit.; JM de

Garanhús a ibid, mesma data, idem MSS JM,

vol. 8, 1852. Poucos dias antes da ocupacão de

Garanhús chegavam a Recife notícias, vindas

de Nazareth, de que tinham partido dessa vila

diversos emissários dos insurretos "para dife-

rentes partes, com o fim de aconselharem a

população a não ceder as armas enquanto S.M.I não concordar em convocar uma assembléia constituinte", numa evidente alusão à suposta natureza praieira da revolta. Cf. Secretário da Policia a Presidente da Provincia, 23.01.1852, em DP, 06.03.1852.

63

DP, 19.01 .1852 tanto à 'pacificação' proposta pelo frade capuchinho, quanto ao binômio Poder Civil/Igreja Católica que o próprio Registro de Nascimentos e Óbitos trazia implícito nos seus postulados. 0 Bispo Diocesano, na sua circular aos párocos das freguesias no inicio da revolta, já tinha feito uma clara advertência aos livres e pobres, alertando-os que "[...] não convém acreditar outras expressões, além das que se contem nesta nossa breve alocução. Considerai sugerida pelo comum inimigo do genero humano outra qualquer doutrina que não seja a Evangélica, que vos anunciamos [...]".58

De fato, no Limoeiro, frei Caetano, longe de reunir as multidões aparentemente apoteóticas que, segundo testemunhas, tinham-se congregado em Pau d'Alho para ouvi-lo falar, teve de enfrentar alguns dissabores. 0 grande desencanto foi a escassa afluência de moradores da freguesia de Bom Jardim às sessões de prédica, fato atribuído a que "[...] infelizmente tem-se espalhado entre a população menos discreta daquella Freguezia, o Sistema do Ateismo, de que me tenho horrorizado por considerar que uma nação que perde o vigor da religião tem rompido o laço social [...]". ${ }^{59}$ No entanto, o frade cumpriu sua missão, convencendo os revoltosos presentes a deporem as armas, penitenciarem-se pelos seus pecados e abandonarem a vila de volta aos seus locais de origem. Entre 19 e 20 de janeiro de 1852, exatamente um mês após o inicio dos distúrbios em Rozário de Cima, a insurreição motivada pelo Registro dos Nascimentos e Óbitos cessou em Limoeiro e frei Caetano, sempre seguido de perto por uma coluna do $9^{\circ}$ Batalhão, dirigiu-se a 'pacificar' Nazareth, Lagôa do Carro e Glória de Goitá.60

A evacuação das vilas de Pau d'Alho e de Limoeiro, na segunda metade de janeiro de 1852, marcou o refluxo da revolta contra o Registro. A agitação continuou em diversos pontos da província, mas era evidente que a neutralização dos focos mais radicais prenunciava o fim da luta. Apenas Nazareth, Bom Jardim, Iguaraçú, na Zona da Mata, e Garanhuns no Agreste meridional, continuaram até o fim de Janeiro sendo palco de confrontos e escaramuças entre tropas do governo e grupos de agricultores e outros livres e pobres, embora fosse patente que se tratava já de ações isoladas, e que a sublevação popular, generalizada, retrocedia - embora se mantivesse vivo o temor da possivel aplicação do famigerado Registro. ${ }^{61}$ Por alguns momentos parecia até que, recuando nos focos originais da agitação, a guerra camponesa se transferia para as regiões agrícolas do Agreste, sobretudo para a montanhosa comarca de Garanhús, cuja vila foi ocupada, ainda em 26 de janeiro, por mais de 300 homens. ${ }^{62}$ Mas já era o canto do cisne, e para finais do mês a revolta dos livres e pobres desaparecia do noticiário e da pauta da Secretaria de Polícia tão subitamente quanto tinha começado, deixando, conforme anunciara com rapidez o Diário de Pernambuco, "os povos dedicados aos cuidados do campo".63 A pax capuchinha era agora apenas quebrada, vez por outra, por minúsculos grupos remanescentes de insurretos, que certamente partiriam, como de outras rebeliões, para o sertão, para a marginalidade e para o banditismo.

Encerrada essa primeira fase da revolta (haveria novos e constantes, mas esporádicos, surtos de inquietação popular nos dezembros subseqüentes) foi possivel para os envolvidos proceder finalmente a um balanço circunstancial. 0 subsídio governamental para os capuchinhos em Pernambuco foi elevado de 840\$000 para 2:400\$000 rs; o Secretário da Polícia pediu exoneração do cargo (recebeu, em troca, férias) e publicou uma extensa e agressiva carta acusando o Presidente da Província de pusilanimidade diante dos praieiros. E, em 29 de Janeiro de 1852, o visconde de 
64

"Decreto No. 907 de 29 de janeiro de 1852. Suspende a execução dos Regulamentos para a organização do Censo Geral do Império, e para o Registro dos Nascimentos e Óbitos", em Colecção das Leis (1852), Tomo XV, Parte 2a., p.19.
65

Relatório do Presidente da Província de Pernambuco, 1850, p.22. Destacamentos de linha estavam estacionados de maneira quase permanente nos municípios de Jaboatão, Escada e Monteiro, enquanto que outras forças se encontravam 'operando' em Ipojuca, Cabo, Santo Antão, Bonito, Brejo da Madre de Deus, Garanhuns e Flores. Dessas 10 localidades, 8 seriam atingidas pela revolta dos livres e pobres um ano e meio depois.
Mont'Alegre voltou ao proscênio, dando por terminado (temporariamente) o episódio e confirmando a vitória parcial dos livres e pobres com as seguintes palavras:

"Hei por bem que, em quanto não for determinado a contrario, se sobr'esteja na execução dos Regulamentos para a organização do Censo Geral do Império, e para o Registro dos Nascimentos e Óbitos, approvados pelos Decretos Nos. 797 e 798, ambos de 18 de junho de 1851."64

\section{0 tempo e o espaço da revolta}

A "Guerra dos Maribondos" em Pernambuco foi um movimento social inserido nos momentos finais da lenta transformação do sistema de controle social do trabalho nas plantations pemambucanas, transformação que, iniciada no final do século XVIII, acelerou-se brutal e definitivamente a partir da proibição de importação de mão-de-obra africana em 1850. Este é, sem dúvida, um dos dados fundamentais para situar contextualmente a revolta e refletir sobre as suas características, embora talvez não seja suficiente para compreender a sua efemeridade, nem sua maior incidência na província de Pernambuco e, dentro dela, em determinadas áreas. Outros elementos e informações de natureza local e micro-regional, atualmente não disponiveis, teriam de ser incorporados na análise para tentar formular quadros explicativos que se aproximassem com maior fidelidade à problemática específica colocada pelo movimento.

Evidentemente, a Revolução Praieira - como fica claro na própria narrativa dos fatos - foi um dado de primeiríssima importância, não apenas na forma e nos rumos da revolta dos livres e pobres contra o Registro dos Nascimentos e Óbitos, mas também nas interpretações contemporâneas do fenômeno, nas vias de ação conseqüentemente adotadas e, quiçá, até na mesma essência popular e anônima da história da sublevação. A Praieira foi, de fato, uma espécie de leitmotiv da "Guerra dos Maribondos", uma sombra que pairou como um fantasma sobre as cabeças das instituições politicas da época ampliando os perigos do levante popular - embora também fosse vital para explicá-lo e, paradoxalmente, para tranqüilizar os oponentes, oferecendo uma causa identificável e assimilável na conjuntura de conflitos interoligárquicos desses anos. E não era para menos. Ainda em 1850, nos últimos momentos da administração do futuro marquês do Paraná - Honório Hermeto Carneiro Leão - na Presidência da Província de Pernambuco, com a Praieira já concretamente derrotada, seus líderes mortos, presos e desterrados, subsistiam fortes receios nos círculos governamentais conservadores de que a faisca da revolta popular se reacendesse a qualquer momento, com a mesma espontaneidade e força arrebatadora com que 0 movimento tinha começado em novembro do 48. Dois anos depois Pernambuco vivia ainda um acentuado clima de tensão política, com diversas regiões, focos centrais da agitação revolucionária, em virtual estado de guerra, ostensivamente ocupadas por destacamentos do insuspeito exército de linha. 65

Mas os anos de 1850/1852 em Pernambuco, além de terem significado um dos períodos mais agitados (que não foram poucos) para a manutenção da ordem vigente, apresentavam também outras peculiaridades que, somadas às anteriores, preparavam o clima ideal para o surgimento de protestos e revoltas populares. As áreas onde a sublevação contra a Registro foi mais radical e virulenta, as comarcas de Pau d'Alho, Limoeiro 


\section{6}

A depressão, como é sabido, iniciou-se no fim da década de 1820, e progrediu até precisamente a metade da década de 1850, quando se iniciou a recuperação que alcançaria o seu momento culminante nos anos 60, por causa de guerra civil nos Estados Unidos. Cf. Burlamaqui, F.L.C. Monographia do Algodoeiro. Rio de Janeiro, Typographia de Nicolau Lobo Vianna e Filhos, 1863; Stein, S.J., The Brazilian Cotton Manufacture. Textile Enterprise in an Underdeveloped Area, 1850-1950. Cambridge. Eisenberg, The Sugar Industry, p.17. Harvard University Press, 1957; Canabrava, A.P., 0 Algodão em São Paulo, 1861-1875. São Paulo, T.A. Queiroz, 2a ed., 1984.

\section{7}

Koster e Tollenare, ja citados, são os exemplos mais conhecidos. Veja-se também Kidder, D.P. Reminiscências de Viagens e Permanência no Brasil (Províncias do Norte). São Paulo, Livraria Martins Editora, 1951.

68

Eisenberg, The Sugar Industry, p.17.

69

Relatório do Presidente de Pernambuco, 1852, p.27. e Nazareth, eram todas pontos focais de regiões produtoras de algodão plantado freqüentemente por trabalhadores livres em terras marginais de engenhos açucareiros- violentamente afetadas pelos últimos anos de um longo ciclo de depressão, decorrente da queda progressiva dos preços do produto no mercado mundial. 66 Alguns centros urbanos dessas comarcas, como Limoeiro e Bom Jardim, tinham sido no primeiro quartel do século florescentes núcleos comerciais que cresciam de maneira notável, atraindo capitais, mercadores estrangeiros e mão-de-obra livre para o plantio da fibra. Diversos observadores contemporâneos deixaram testemunhos claros do efeito que a difusão do cultivo do algodão continuava a ter, nesses anos das primeiras décadas do século XIX, sob as comunidades de livres e pobres no campo, que com ele se integravam em números crescentes aos circuitos produtivos e mercantis do complexo agro-exportador escravista. ${ }^{67}$ Porém, embora a partir de meados da década de 1850 as cotações voltassem a subir, os anos de 1850-1852 foram de crise para os livres e pobres das zonas algodoeiras, onde se acumulavam vastos contingentes de mão-deobra livre desocupada. Ao mesmo tempo, num mecanismo mais do que conhecido na história agrária do Nordeste Oriental, as áreas de produção de cana viviam momentos de notável expansão. ${ }^{68}$ De 507 engenhos contabilizados em 1852 pelo Presidente da Província nas comarcas de Recife, Goiana, Vitória de Santo Antão, Pau d'Alho, Nazareth Cabo, Rio Formoso e Bonito, 137 tinham sido construídos nos 10 anos anteriores. ${ }^{69}$

Certamente esse quadro de depressão nas áreas e atividades próprias dos agricultores livres e pobres, conjugado com a expansão de engenhos e canaviais, era já suficiente para criar uma situação de tensão e conflito potencial, embora não necessariamente uma sublevação - como não tinha acontecido em situações similares anteriores. Mas é legitimo especular que essa conjuntura de desemprego generalizado nas comunidades de livres e pobres e de aumento simultâneo das necessidades de força de trabalho nas plantations açucareiras e algodoeiras, exatamente no momento em que se fechava a porta de entrada para novas levas de escravos africanos, pode ter dado ao Registro dos Nascimentos e Óbitos, com todos seus trâmites e formalismos ligados ao poder da burocracia governamental, a potestade suficiente para detonar finalmente a insurreição.

Contudo, o Registro não era a única ameaça que parecia pairar sobre as cabeças dos homens e das mulheres livres e pobres nesse meio de século; outras, e possivelmente mais sérias, fechavam já o horizonte e restringiam cada vez mais os espaços produtivos e sociais em que se movimentavam - atrelados, porém marginais - esses numerosos segmentos da população nordestina. 0 Regulamento do Registro de Nascimentos e Óbitos era na realidade, como já foi dito, uma espécie de primo pobre de inovações jurídico-institucionais de primeira grandeza no Brasil escravista. De fato, no mesmo ano de 1850 em que fora promulgada a Lei Eusébio de Queiroz, tinha sido sancionada também a Lei de Terras, que vedava as possibilidades de acesso à terra por outras vias que não a herança e a compra, e dificultava - e condicionava políticamente - a posse sem intervenção do mercado, na medida em que a fazia explicitamente ilegal.

A nova legislação agrária, ao proibir a posse, cancelava o caminho tradicionalmente utilizado na reprodução da esmagadora maioria dos pequenos produtores não-proprietários - que representavam, por sua vez, a esmagadora maioria da população de agricultores livres e pobres do Brasil -, e reforçava enormemente o poder dos proprietários legais para 
70

Como foi visto em páginas anteriores, uma das formas encontradas pelas autoridades pernambucanas para orientar as tarefas de 'persuasão' junto aos insurretos era, precisamente, garantir que o Regulamento não só não ameaçava a liberdade de ninguém, como que oferecia maiores garantias dessa condição aos que fossem efetivamente livres. É claro que esse tipo de argumento não deve ter sido capaz de atenuar a desconfiança da população juridicamente livre, sobretudo daquela que levava consigo o estigma da cor, habituada ao proverbial arbitrio de uma sociedade escravista, enquanto que, por outro lado, deve ter soado como uma definitiva ameaça para os incalculáveis ex escravos que, fugidos das plantations, evitavam igualmente os quilombos e preferiam diluir-se nas comunidades camponesas ou nas áreas urbanas. Para 0 argumento governamental cf. Presidente da Provincia a Juizes de Direito. 'Circular', em DP, 03.01.1852.

\section{1}

Numa clara evidência de que o problema do recrutamento e a oposição ao Registro eram encarados pelos sublevados como aspectos diversos do mesmo dilema, os recrutas mantidos nas cadeias públicas a espera da sua remoção para serem integrados a corpos da Guarda Nacional foram sistematicamente libertados nas vilas que, como Limoeiro e Pau d'Alho, cairam nas mãos da insurreição. JD do Limoeiro a Presidente da Provincia. 05.01.1852, em MSS $J D$, vol.cit. Sobre as Ordenanças, cf. Palacios, Campesinato e escravidão, cap.V.

72

Por exemplo, JD de Santo Antão a Presidente da Provincia. 21.12.1852, loc.cit. executar despejos ou agravar as condições de ocupação das terras marginais das plantations. 0 Registro e a Lei do Censo dirigiam-se explícitamente a contar e descobrir o número dos livres e pobres, e com isso a fazê-los públicos e notórios perante a autoridade do Estado, com nome, endereço e situação familiar; além do mais, dificultava enormemente a transposição da barreira da escravidão, pois aperfeiçoava os mecanismos de identificação da condição jurídica desses setores da população, dentro dos quais escondiam-se muitos devedores da lei, fugitivos do cativeiro. Em certo sentido, o Registro dos Nascimentos e a Lei do Censo nada mais eram do que instrumentos paralelos à Lei de Terras com relação à força de trabalho. Se esta pretendia conhecer e reformular a estrutura fundiária do pais, legitimando a propriedade considerada legal, e retirando a terra de quem a não possuísse pelas vias tidas como aceitáveis pelo novo sistema jurídico, o Registro era sua contrapartida perfeita em termos da condição jurídica dos livres e pobres: confirmava a liberdade dos que podiam comprovar essa abençoada condição, e ameaçava com reconduzir à escravidão os infelizes que não contassem com a documentação necessária para fundamentar sua independência pessoal. ${ }^{70}$ Por último, camponeses e demais livres e pobres viam-se agora também às voltas com outro grande perigo: o recrutamento para a Guarda Nacional, um processo sabidamente de grande violência, não muito diferente dos procedimentos de captura e condução de escravos fugidos para as cadeias públicas das vilas e das cidades da região. Para as famílias de agricultores livres e pobres a Guarda Nacional, como as antigas Ordenanças, representava perigos concretos e tangiveis. Em primeiro lugar, sangrava as unidades produtoras de força de trabalho muitas vezes imprescindivel para a própria sobrevivência do grupo, obrigando a um remanejamento de recursos que alterava, sempre em detrimento do equilíbrio, toda a vida familiar. Em segundo lugar, atacava a autonomia dos livres e pobres e fazia ainda mais estreita a dependência para com os proprietários de terras, todos eles 'oficiais' da Guarda, na medida em que sua intervenção era por via de regra crucial para o sorteio dos recrutáveis. ${ }^{71}$ Não era, pois, de se estranhar que em diversos pontos das áreas conflagradas pela revolta contra o Registro surgissem irmanados os protestos contra os dois regulamentos. Nem que os efetivos dessa milícia, esmagadoramente provenientes de famílias camponesas e de aglomerações de livres e pobres 'vadios', fossem considerados por várias autoridades municipais e provinciais como aliados dos revoltosos, literalmente farinha do mesmo saco. ${ }^{72}$

Porém, embora esse conjunto de ameaças pairasse de maneira geral sobre todos os livres e pobres, a revolta não ocupou a totalidade da província (apesar de estarem incluídas no mapa dos distúrbios as regiões produtivas mais importantes, com a ressalva do extremo sul da zona da mata), não esteve limitada as áreas deprimidas de cultivo do algodão, pois outras zonas do interior, também ocupadas por esse produto, não foram, ao que parece, afetadas, e teve pontos diferenciados de intensidade e de duração. Será possivel explicar todas essas variações?

Nenhuma situação histórica se insere em padrões de determinação homogêneos, ignorando as próprias diversidades existentes nas situações sociais e econômicas concretas que compõem uma conjuntura particular. No caso da "Guerra dos Maribondos", como no de outros fenômenos sociais de igual ou maior dimensão, é mais fácil - e convincente - apresentar as razões pelas quais o movimento efetivamente aconteceu em algumas áreas, do que explicar porque tantas outras permaneceram alheias à revolta dos 
livres e pobres. Para esses casos somente parece possível, por enquanto, oferecer alternativas vagas e constrangedoramente simplistas, a espera de um estudo mais abrangente sobre a resposta que diversas comunidades de livres e pobres, não participantes da revolta, deram à promulgação do Registro -e à das outras medidas legais mencionadas. Sob essa frágil base explicativa algumas reflexões mais aproximadas podem ser feitas.

Como já foi mencionado, o centro nevrálgico da revolta contra o Registro dos Nascimentos e Óbitos esteve constituido pelas comarcas de Pau d'Alho, Nazareth e Limoeiro, um 'triângulo' de agricultores livres e pobres de origem colonial, região de produtores de algodão e gêneros alimentícios e, em menor medida, a partir da primeira metade do século XIX (Pau d'Alho e Limoeiro), de cana de açúcar e produtos pecuários. A eclosão da revolta precisamente nessa área, e a dimensão e gravidade incomparáveis que ali atingiu, foi hipotéticamente atribuida em páginas anteriores à crise do algodão, à concentração de livres e pobres nessas comarcas por causa da prévia difusão do seu cultivo e, finalmente, à pressão exercida sobre homens e terras pelo crescimento da plantation. Uma segunda onda de intensidade da revolta, menor que nos três casos mencionados, afetou as comarcas da chamada Mata Seca, sobretudo Goiana e os municipios ao norte do Recife, tradicionais empórios produtores de açúcar, embora consideravelmente menos férteis e ricos do que os seus congêneres da Mata Sul. Sintomaticamente, foi nessas áreas do norte da região açucareira onde, por causa da menor afluência dos grandes proprietários de terras, a transição do escravismo ao chamado trabalho livre se daria mais depressa, a partir de finais da própria década de 1850. 0 ano de 1851, no entanto, parece ser uma data prematura demais como para supor que estivesse já acontecendo o esvaziamento da Mata Seca e a substituição sistemática da sua força de trabalho escrava pela de agricultores autônomos e outros homens livres e pobres. Mas é possivel supor, sim, que dada a vizinhança dessa área com as zonas decadentes de produção de algodão e a constante comunicação entre ambas as regiões agrícolas, levas de livres e pobres expulsos pela crise da sua principal atividade produtiva teriam migrado para as comarcas açucareiras imediatamente ao norte - muito menos monocultoras do que, por exemplo, Água Preta, Gameleira ou Escada, ao sudoeste do Recife -, à procura de terras apropriadas para culturas de subsistência em áreas de clima mais chuvoso do que o agreste algodoeiro. Isso, é claro, sem descartar a hipótese da atração exercida pelas plantations sobre uma população crescentemente pauperizada pela ruína regional do algodão. De qualquer maneira, haveria que apelar novamente para dados demográficos (entre outros) para corroborar essa possibilidade, e para fundamentar a hipótese de que os diferentes níveis de intensidade na incidência da "Guerra dos Maribondos" eram indicativos da maior ou menor concentração de homens livres e pobres no Pernambuco da metade do século XIX.

Finalmente, um terceiro nivel de gravidade e de duração da revolta agrupa, grosso modo, os municípios ao leste e ao sul do Recife e várias das suas freguesias: Jaboatão, Cabo, Muribeca, todos na rica região da Várzea, e mais Vitória de Santo Antão, Escada, Ipojuca, Serinhaem, assim como a comarca de Garanhús, então abrangendo praticamente todo o agreste meridional e a boca do sertão. Com exceção da própria vila de Garanhús, em nenhuma dessas circunscrições aconteceram ocupações de vilas, cidades ou cabeceiras de municípios, como sucedeu na região algodoeira setentrional, e a freqüência de assaltos a casas grandes e sedes de propriedades 
rurais foi sensivelmente menor do que na mata seca. Os efetivos dos sublevados também ficaram muito aquém das forças mobilizadas pela revolta no norte da província e, por último, o tempo de duração dos distúrbios foi mais curto. Por outro lado, ações individuais de moradores de propriedades contra os senhores parecem ter tido uma maior incidência relativa nesta área do que nas outras zonas, onde predominaram as manobras e os movimentos coletivos. 0 leste e o sul da Zona da Mata, no entanto, receberam das autoridades provinciais uma atenção desproporcional à dimensão local da revolta, porém certamente condizente com a grande importância econômica e política que representavam para a oligarquia agrária pernambucana.

Com relação ao tempo específico do início e do fim da revolta há, por enquanto, pouco a dizer, já que o movimento ficou estritamente contido entre os momentos de difusão da informação sobre o decreto do Regulamento e a proximidade da sua data de aplicação, por um lado, e o recuo do governo provincial e as missões de pacificação de frei Caetano, pelo outro. Existe, não obstante, outro dado de primeira importância: a revolta contra o Registro coincide exatamente com os meses mortos do calendário agrícola das comunidades de agricultores de subsistência do Agreste e da Zona da Mata de Pernambuco.

\section{As causas gerais do conflito}

Dentro do conjunto de razões, verídicas ou imaginárias, esgrimidas pelos autores das fontes para explicar o estouro da revolta e sua rápida propagação, não interessa aqui o desvelamento de eventuais causas 'reais' que levaram milhares de livres e pobres, homens e mulheres, velhos e crianças, a tomarem em armas contra as leis e contra o Estado. Interessa, sim, o arrolamento de todas as principais motivações alegadas, presumidas ou insinuadas, quer com caráter explicativo, quer com intenção acusatória, pois a análise desse conjunto de argumentos certamente contribuirá, mais do que o simples isolamento de uma suposta 'razão central', à compreensão do 'sentimento' coletivo e do imaginário, tanto dos livres e pobres e seus aliados, quanto dos seus adversários na 'Guerra dos Maribondos'.

A causa mais citada, como é evidente da própria leitura das fontes, esteve constituida pelo medo coletivo da população pobre livre do interior de Pernambuco de perder, em função da sua pobreza, a sua condição de liberdade. Dissemos que a pobreza foi o fundamento do temor que assaltou os livres e pobres diante do Registro de Nascimentos e Óbitos, porque parece evidente a homogeneidade econômica dos participantes da revolta, embora diferenciados em termos de grupos sociais. Foram majoritariamente aqueles que se encontravam nos confins da estrutura social do escravismo, provavelmente até inferiores ao escravo em termos de condições objetivas de sobrevivência - e sobre isso os viajantes estrangeiros que visitaram o Brasil no começo do século XIX deixaram abundantes testemunhos -, mas separados dele, ainda, pelo atributo jurídico da liberdade. Mas já parece ser o embrião de um medo de classe.

Ao lado dele aparece a justificativa poltíco-partidária, conjuntural, isto é, os boatos 'mal-intencionados' sobre as perversas intenções ocultas da lei, naturalmente atribuídos aos inimigos do governo. Esta versão, embora não explique plenamente o temor e se limite a encontrar a sua causa, ajudou os conservadores a entenderem, na sua lógica peculiar, a transformação da resistência dos livres e pobres num movimento armado. Nela subsiste, no entanto, como elemento primordial para explicar a revolta, a permeabilidade 
73

JD de Vitória de Santo Antão a Presidente da Provincia. 06.01.1852, em MSS JD, vol.cit

74

Relatório do Ministério do Império. 1852, p.17. 0 próprio Figueira de Mello reconheceu que 0 Regulamento causava "sem motivos violencias e despezas aos que querem baptisar seus filhos ou parentes". Secretário da Policia a Delegados da Provincia. "Circular", 30.12.1851, in DP, 13.02.1852. do imaginário dos camponeses e demais camadas de livres e pobres à idéia -'a falsa idéia'- da sua iminente escravização, seja como resultado da sua pobreza, seja como natural conseqüência de uma liberdade 'ilegal' - outra 'idéia falsa' -, seja, enfim (mas não exclusivamente, como acreditaram alguns observadores dos acontecimentos, iludindo cronistas e historiadores posteriores), por uma determinada cor da pele. 0 que interessa é que para os livres e pobres que habitavam o interior de Pernambuco em 1850/1851, a escravidão aparecia no seu horizonte social como um futuro possivel e, em determinados momentos, talvez iminente. E o fato de que essa ampla e incerta possibilidade tenha estado representada não só pelos objetivos ocultos do Registro - ou do Regulamento da Guarda Nacional - mas, sobretudo, pelo incontestável argumento de que, exatamente a partir desses mesmos anos 'os Inglezes não deixão mais entrar Africanos'.73 Essa afirmação parece autorizar a hipótese de que esses segmentos da população livre rural, supostamente embrutecidos pela ignorância e pelo isolamento, podem ter tido conhecimento, já fosse pela sua própria percepção ou por informações 'externas', das linhas estruturais do sistema socioeconômico no qual estavam inseridos, e do temivel futuro que o processo em andamento Ihes deparava.

Por outro lado, ao longo da revolta pernambucana problemas concretos colocados pela letra do Regulamento, criticamente sensiveis para as familias dos livres e pobres, transpareceram uma e outra vez, confundindo e misturando as motivações centrais dos participantes da insurreição. Problemas que diziam especificamente respeito à relação dos indivíduos com Deus e com o Estado, aos quais Mont'Alegre havia aludido nos seguintes termos:

"[...] as disposições dos Arts. 23 e 24, que proibem a inhumação dos cadáveres, e o baptismo dos recem nascidos (salvo o caso de evidente perigo de vida) sem que seja presente a certidão de registro, que aliás, na forma do Art. $3^{\circ}$ só pode ser passado pelo Escrivão de Paz do respectivo districto, excitarão algum clamor contra o Regulamento [...] De diversos pontos chegarão representações ao Governo, ponderando não só a impossibilidade de fazerse em 24 horas a participação do fallecimento [...] mas também a de exigirse para a baptismo a certidão do registro de nascimentos em lugares longinquos e ermos, onde de ordinário só he administrado aquelle sacramento nas visitas, que fazem os Vigários ao centro de suas Parochias por occasião da desobriga quaresmal; e se bem que ao começo parecesse exagerada a enunciação de taes difficuldades, as informações ministradas pelos Presidentes de algumas Provincias, e o testemunho do douto Metropolitano, e dos Reverendos Bispos de Mato Grosso e Pernambuco, dissiparão todas as dúvidas'."74

De fato, o Regulamento tinha sido elaborado por funcionários administrativos instalados nos seus gabinetes da Corte, e por isso basicamente ignorantes das verdadeiras condições de vida da maioria da população do país que regulamentavam. Era claro que numa sociedade fundamentada em preceitos da religião católica, a questão de não poder enterrar um defunto ou batizar uma criança de acordo com a liturgia estabelecida equivalia não apenas ao risco da condenação eterna, como a renunciar à tentativa de ressarcir-se, na outra vida, das misérias desta. E tinha mais: o Regulamento do Registro, ao indicar os Escrivães de Paz como os encarregados de fornecer e autenticar os registros, introduzia violentamente, de um 
75

Documento dos revoltosos ao Delegado Suplente de Pau d'Alho. 02.01.1652, em DP, 16.01.1852. Cursivas minhas.

\section{6}

JD do Limoeiro ao Presidente da Província. 11.01.1852, em MSS JD, vol. cit. Cursivas minhas.

77

JD do Limoeiro a Presidente da Provincia, s/d (fevereiro de 1852], em MSS JD, vol. cit.

78

Senhores de engenho na freguesia do Cabo, participaram das primeiras linhas de combate da Revolução Praieira. Para maiores detalhes, cf. Carneiro, op.cit., passim. Antonio já estava morto na época do Registro.

79

Secretário de Policia a Presidente da Provincia em DP, 'Publicações a Pedido'. 15.02.1852, 17.03.1852. momento para outro, o poder do Estado e sua representação política local no mais íntimo da vida das familias dos livres e pobres: "[...] sem certidão delles não se poderá fazer uma criança christã [...]".75 Assim, o destino dos livres e pobres na outra vida passava a depender, como já dependia nesta, dos mesmos ordenadores seculares das relações sociais, o Estado e as estruturas políticas locais. Mas o Registro -e junto com ele a menos atacada, porém não menos temida, 'lei do censo'- tinha a propriedade de invadir a intimidade doméstica de outras formas, abrindo o núcleo protetor da unidade familiar a uma intervenção cada vez mais constante e institucionalizada. No Limoeiro, no auge da ocupação armada da cidade, o Juiz de Direito captou essa preocupação no discurso dos revoltosos, que, irados, exigiam "que thes entregasse a Ley que os obriga a dar os nomes dos seus filhos aos Escrivães de Paz".76

A respeito das denúncias de infiltração política nas fileiras dos livres e pobres como tendo sido a verdadeira causa da revolta dessa camada 'ordeira' da população, é bom lembrar que esse tipo de advertências partiram geralmente de apenas alguns lugares (Escada, Pau d'Alho, Limoeiro, Iguaraçú e Goiana). As provas, por sua vez, não parecem ter sido suficientemente convincentes como para aceitar a teoria de que sem os praieiros a revolta do Registro não teria sido possivel. Contra as declarações formais de reprovação do movimento apresentadas por Castro Tavares e Loyola, e contra outras várias testemunhas da abstenção dos liberais na luta dos livres e pobres, o Chefe da Policia e alguns dos seus subordinados só tinham a oferecer eventuais palavras-de-ordem proferidas pelos revoltosos: "morram os guabirús", "viva a liberdade", sendo que numa dessas manifestações os insurretos deixaram tudo mundo perplexo com os gritos de -também- "morram os praieiros!".77

Por outro lado, nenhum praieiro notável dos muitos ainda vivos e em liberdade, além dos irmãos Antonio e Miguel Afonso Ferreira, vagamente mencionados como sendo vizinhos de alguns engenhos da Escada dos quais partiam índios e moradores para se juntarem à rebelião, foi formalmente envolvido nos conflitos, nem como participante nem como instigador. ${ }^{78}$ Mas o 'zelo' político-policial de Figueira de Mello continuou até o fim sustentando exclusivamente a tese da ingerência dos derrotados do '48 como a única causa da revolta armada dos livres e pobres. Assim, na sua carta publica ao Presidente da Província, defendendo sua participação no combate ao movimento contra o Registro e acusando o Presidente de fraqueza perante os liberais, afirma:

"[...] he do partido opposicionista, que tem constantemente emanado todas [as] insinuações, de que os seus adversários pretenderam e pretendem escravisar politicamente o paiz, e tirar a liberdade civil aos cidadãos de cor [...] [a infiltração só começou] quando a todos parecia, que desses movimentos podia rezultar uma questão de rasas, e della todos os horrores que qualquer adivinha [...]."79

Mas independentemente da eventual participação ou não de ex praieiros ou liberais em geral na revolta contra o Registro dos Nascimentos e Óbitos, o que interessa realmente para os nossos fins é o espanto e a descrença dos responsáveis pela administração do Estado, tanto no nível municipal, quanto no provincial e central, perante a possibilidade de uma insurreição popular - nem de senhores nem de escravos -, dotada de causas próprias, de reivindicações especificas, e revestida de uma viru- 
80

A frase é de autoria do Inspetor de Índios da Escada. Inspetor de Indios da Povoação da Escada a Subdelegado do $1^{\circ}$ Districto de Escada. 02.01.1852, in DP, 18.02.1852.

81

Secretário da Polícia a Presidente da Província, ofício citado em nota 86 lência que transpunha todos os limites de comportamento social e político dos segmentos subalternos da sociedade escravista. Dessa incapacidade dos grupos dirigentes em conceber os livres e pobres como atores interessados na elaboração de decisões que Ihes afetavam intimamente, mais do que de provas ou evidências, é que surgiram os boatos e as versões sobre a manipulação política, a ingerência de provocadores e pessoas mal intencionadas, a visão da revolta contra o Registro, enfim, como sendo apenas um movimento detonado pelos "inimigos do Governo", isto é, "o praieiro que tudo trama". 80

Esses tipos de interpretações da revolta contra o Registro permitem perceber não só a volatilidade do clima político de Pernambuco no afterday da Revolução de 1848, como também, e sobretudo, a visão que o nascente Estado nacional projetava da grande massa da população que comandava, um pouco sem o querer, nesses idos de 1850/1851. De fato, todas as referências à imprescindibilidade da ingerência praieira para explicar a revolta dos livres e pobres decorriam de duas constatações principais, transformadas em premissas da interpretação. A primeira repousava no fato de que a insurreição não esmorecia diante das rápidas concessões do governo. Assim, independentemente da suspensão da aplicação do Decreto, da não efetivação das prisões e da trégua no recrutamento, continuava "a Província ainda a agitar-se dolorozamente sem obter a preciza tranquilidade'" 81 A segunda, a que mais interessa pelas suas implicações sociais, centrava-se na barreira que a 'ignorância' dos livres e pobres havia sempre colocado à formulação de reivindicações próprias, e que, neste caso específico, teria de render impossivel para o "povo incauto" detectar, sem ajuda de extremistas, os perigos implícitos tanto no Registro dos Nascimentos, quanto na Lei do Censo e no novo Regulamento da Guarda Nacional, e resumir tudo o que o esperava nas décadas por vir num corriqueiro termo da época: cativeiro. Dessa maneira, a resposta dos governantes e dos proprietários de terras e de escravos perante uma revolta autônoma de grupos subalternos da sociedade agrária foi procurar explicações tranqüilizadoras não na mudança que estava de fato acontecendo, mas sim nos alicerces da velha construção, na perversidade dos adversários internos ao sistema, e na estupidez dos camponeses.

Assim, a versão definitiva do movimento dos livres e pobres contra o Registro dos Nascimentos e o conjunto de medidas dirigidas contra suas formas de organização social em 1850-1852 tirou-Ihes qualquer mérito como protagonistas da sua própria história, como atores na sua própria revolta, e os devolveu, imperativamente, de novo expropriados, ao lugar da mais longínqua insignificância - do qual, segundo a mentalidade conservadora, jamais poderiam ter saído sem a ajuda do pernicioso, mas legítimo Partido Liberal. Essa nova e sumária desaparição dos livres e pobres da história -e da historiografia - do Brasil foi praticada, com brilho e coerência impecáveis, por Eusébio de Queiroz, então Ministro da Justiça:

"[...] a propaganda, que procura por meios revolucionarios reformas radicais nas instituições do paiz, continua descomedida em sua imprensa; reconhecendo porém que suas declamações não encontrão apoio, recorre a novos meios [...] Ahi encontrão explicação os movimentos sediciosos, a que arrastarão a gente mais rude e credula por ocasião de executar-se o Regulamento No. 798 de 18 de junho do anno passado [...] alguns agentes da propaganda, mais soffregos e menos reflectidos, entenderão que era chegado o momento de crear embaraço ao Governo [...] e puzeram em 
82

Relatório [...] do Ministério da Justiça [...] 1852, pp.3-4. Cursivas minhas.

83

Delegado de Nazareth a Secretário da Polícia, 26.12.1851, em DP, 12.02.1852; JM do Bonito a Presidente da Província, 27.12.1852, em MSS JD, vol.7, 1851; Secretário da Polícia a idem. 04.01.1852, em DP, 17.02.1852; Delegado do Limoeiro a Secretário da Polícia, 12.01.1852, em $D P, 02.03 .1852 ;$ JP do $1^{\circ}$ Districto da Escada a Presidente da Provincia, 10.01.1852, em MSS JP vol.cit.

84

JM do Bonito a Presidente da Província, oficio citado. campo a sedição, agitando o espirito da gente menos ilustrada nas Províncias de Pernambuco, Alagoas, Parahyba e Sergipe [...]."82

Junto com os personagens principais da revolta contra o Registro dos Nascimentos e Óbitos, assim varridos impiedosamente e despojados sem cerimônia de qualquer vestígio de autonomia até na sua capacidade de dizer não, foram-se também algumas características inquietantes do movimento popular que os assustados delegados e juizes do interior pernambucano tinham apreendido nessa brevíssima cena, durante a qual camponeses e livres e pobres conseguiram atrair a atenção da platéia - que depois os vaiou ao achar que eram apenas marionetes. Voltaram ao cuidado das suas terras o dos seus plantios, mas deixaram difundida a impressão de que, a despeito de serem 'ignorantes' e 'crédulos', eram sobretudo potencialmente subversivos, portadores de 'principios sediciosos' 83 e, sobretudo, de um perigoso 'espirito de oposição a lei'. 84

\section{Sobre a natureza da 'guerra dos maribondos'.}

A 'Guerra dos Maribondos' aparece nas fontes dotada de características diversas, naturezas várias e, com freqüência, conteúdos e atributos conflitantes. Uma boa parte da documentação, e dentro dela todas as fontes consultadas no nível ministerial, refere-se à revolta como um movimento que foi protagonizado pelos "homens de cor", pobres e livres, contra os quais, supostamente, dirigiam-se as instruções do Regulamento do Registro de Nascimentos e Óbitos. Outras fontes são mais generalizantes ao identificar os participantes ativos nos distúrbios, caracterizando a insurreição como um conflito, provocado pelos "homens pobres e livres", "a maioria do povo", "os povos" de determinada comarca, "a gente baixa", "o povo meúdo", "as classes mais baixas", etc. Este tipo de fontes são, sem dúvida, as mais numerosas dentro do limitado universo de evidências consultado até agora. Por último, uma terceira vertente documental informa sobre um movimento de 'camponezes' ou 'matutos'. Temos pois definições de cor, classe e função social ou produtiva. Um análise apressado poderia levar a seguinte, simples conclusão: os homens livres e pobres de Pernambuco na metade do século XIX eram predominantemente negros e mulatos, e constituiam, em termos produtivos, o segmento camponês da agricultura regional.

A questão da natureza do movimento contra o Registro tem, é claro, uma grande importância no âmbito desta discussão. Da sua elucidação - a revolta como tendo sido um processo restrito à população não-branca livre, ou pelo contrário, um fenômeno que atingiu, sem distinção de cor, a grande maioria da população pobre livre - depende a possibilidade de considerar o movimento uma insurreição inserida na crise terminal do escravismo, mas ainda ostentando os padrões habituais de conflito nesse tipo de sociedade; ou então, como um processo que superava já esses cânones e se enquadrava, precursoramente, nos movimentos sociais de uma estrutura social e produtiva que se movia na direção de superar a vestimenta estamental do Ancien Régime para adotar, de maneira crescente, uma estrutura de classes própria de uma sociedade constituída com base no capitalismo agrário, e historicamente determinada, na sua particularidade, por séculos de trabalho compulsório. Infelizmente as evidências de um e de outro lado são até agora frágeis e esparsas demais para permitir fazer afirmativas consistentes. Outrossim, talvez seja teórica e metodologicamente ilusório esperar que a revolta contra o Registro de Nascimentos, ao final uma sublevação sem 
importância, possa resolver questões de tal magnitude, embora sempre reste a esperança de que, pelo menos, aporte subsídios. 0 que se segue, pois, são algumas tímidas indicações e indícios, além, é claro, de diversas obviedades.

Esta insistência em discutir problemas e formular questões sobre os quais se não têm maiores informações pode parecer simples teimosia, talvez até necessidade. Se juizes e delegados, ministros e presidentes, bispos e chefes de polícia, deixaram escrito que a revolta contra o Regulamento do Registro dos Nascimentos e Óbitos tinha sido protagonizada pelos "homens de cor", insuflados por liberais extremistas, por que querer complicar as coisas e procurar segundas ou terceiras intenções? Bom, primeiro, por um simples dever de ofício. Segundo, sobretudo, porque o que constitui até agora o conjunto da documentação, ao qual nenhum dos participantes teve acesso, mostra que o espaço intencional existe. Terceiro porque tanto a explicação racial quanto a política parecem dirigir-se, na verdade, a desvirtuar e a ignorar - com muita probabilidade involuntariamente - o caráter 'de classe' do movimento. Nesse sentido pode não ser simples coincidência o fato de que os documentos em que a revolta aparece mais particularizada, mais restrita, mais simplificada sejam ao mesmo tempo os de maior grau de elaboração e, sintomaticamente, os destinados à leitura pública: Relatórios de Ministros do Império e da Justiça, Relatórios de Presidentes de Província, editoriais do Diário de Pernambuco, etc. É precisamente nesse tipo de fonte onde o movimento se encontra mais disfarçado.

Parece estar fora de dúvida que o universo social coberto pela revolta esteve localizado no que diversas fontes classificam freqüentemente como "a última ralé", isto é, o fundamento inferior da estrutura de classes, além do qual reinava já o exército dos compulsoriamente cativos. Nesses segmentos da população das áreas atingidas pela revolta, a propagação da insurreição parece ter sido geral, ao ponto de ter forçado em determinado momento o próprio Diário de Pernambuco a abdicar da sua versão favorita de uma sublevação meramente episódica e conceder que se tratava en realidade de um movimento de massas:

"[...] Pouco conscio dos seus direitos [...] o nosso povo do interior cahiu no deploravel e reheprensivel excesso de tentar opor-se a execução do dito Regulamento [...]. As comarcas de Nazareth, Goiana, S. Antão, Iguarassú, Rio Formoso; as freguesias de Ipojuca, Comarca do Cabo, Buique, de Garanhus, Jaboatão, S. Lourenço e Muribeca da capital, foram também theatros de movimentos e perturbações mais ou menos pronunciadas no mesmo sentido [...]." 85

Algumas fontes permitem, por outro lado, focalizar de maneira mais aproximada o quadro geral desse 'povo do interior' sublevado contra o Regulamento do Registro. Nelas se indica com freqüência o fato de que os grupos de insurretos estavam integrados majoritariamente por individuos, homens e mulheres, residentes nas freguesias e comarcas afetadas, porém não habitantes das vilas nem das povoações, e sim agricultores livres e pobres procedentes de pontos distantes, raros freqüentadores dos centros urbanos de então. Ao lado deles aparecem também numerosos moradores e agregados de engenhos próximos às sedes das freguesias, numa indicação clara de que a revolta quebrou as linhas que separavam os agricultores dependentes dos engenhos e das plantations algodoeiras dos seus congêneres autônomos do interior mais ou menos remoto, posseiros de terras devolutas ou ocupantes de propriedades improdutivas. Também abalou uma 
86

Relatorio do Presidente de Pernambuco, 1852, p.3.

87

DP, 19.01.1852. das vigas mestres do sistema de controle social do trabalho do agricultor dependente, ao permitir que moradores atrelados a engenhos desafiassem os 'direitos' do senhor. 0 incidente do Cabo, onde vários deles "chegaram ao arrojo" de resistir aos despejos ordenados pelos proprietários chama a atenção para um outro contexto em que se desenvolvia a "Guerra dos Maribondos", e que punha em evidência os problemas gerados pela convivência entre plantations escravistas e agricultores livres e pobres, embora dependentes do proprietário da terra. Figueira de Mello constatou que o comportamento dos moradores parecia estar mudando, ao reclamar e cobrar dos seus subordinados a falta de informações sobre "tão extraordinário acontecimento".

Como já foi dito, a despeito de todos os esforços, nem a polícia provincial, nem os diversos magistrados interessados, nem os ministros conseguiram provar definitivamente a natureza partidária do movimento dos livres e pobres, nem tampouco conseguiram - e daí decorre grande parte da fraqueza dessa interpretação - identificar eventuais cabeças ou líderes do movimento. A "Guerra dos Maribondos" foi uma rebelião sem comando, na qual milhares de camponeses e outros livres e pobres

"[...] desenvolvendo o aparato de uma sublevação que parecia dirigir seus ataques contra condições vitais da nossa existência social, levavam inquietação a todos os animos, e prometiam os maiores excessos contra a ordem pública, sem saberem alias o que queriam, e sem terem chefes, nem reconhecerem direção alguma [...]."86

A composição fortemente camponesa da "Guerra dos Maribondos" emerge mais claramente do registro de outros fatos, desta vez vinculados às circunstâncias do seu término, além da referência explícita do Diário de Pernambuco aos "camponezes e matutos [que] se amotinaram e lançaram mão das armas". 0 mesmo jornal, falando no final de janeiro sobre o sucesso da "pacificação" realizada por frei Caetano de Messina, dava a revolta como encerrada e anunciava que passada a tempestade tudo voltava ao normal, "achando-se os povos dedicados aos cuidados do campo". ${ }^{87}$ Esta constatação conduz à última evidência, tanto sobre o caráter da insurreição quanto as determinantes do seu súbito fim em fevereiro de 1852. Como já indicamos, a "Guerra dos Maribondos" esteve perfeitamente delimitada pelo ciclo anual das culturas de subsistência das comunidades envolvidas na luta - sobretudo aquelas do Agreste e da Mata Norte. Precedido pelas colheitas de verão, esse breve fureur paysanne desenvolveu-se durante os meses mortos de dezembro e janeiro - quando alcançou sua maior intensidade - e recuou, abruptamente, no começo de fevereiro, no tempo certo para que os combatentes preparassem a terra para receber, em março, os novos plantios de milho e de feijão.

Mas se a revolta contra o Registro foi um fenômeno predominantemente camponês, não excluiu outros participantes, como também não se orientou de acordo com as diversas tonalidades da pele dos livres e pobres. 0 Registro, na realidade, ameaçava ao conjunto da população que não pertencesse aos círculos privilegiados, aos estratos médios ou aos escravos. 0 seu famigerado Regulamento, estopim da crise, vinha acompanhado por um modelo de 'mappa dos nascimentos' que devia ser observado e preenchido. Nesse modelo, talvez mais do que na letra do Regulamento, podem ter estado contidas as maiores ameaças à liberdade dos pobres, independentemente da sua cor ou da base econômica da sua subsistência, pois o 
"Decreto", em Colecção das Leis, 1851, t. XIV, Parte $2^{\mathrm{a}}$, pp.170-174. mapa não pedia nenhuma informação referente a essas duas situações e, curiosamente, numa sociedade escravista, desinteressava-se por completo com relação ao atributo racial que estava precisamente na base da estrutura social. Por outro lado, ou melhor, paralelamente, o parágrafo $2^{\circ}$ do Art. $7^{\circ}$ pedia a identificação da cor apenas no caso de crianças escravas, enquanto ignorava a necessidade de apontar da mesma forma a cor dos livres e pobres. Não havendo essa especificação, os 'brancos' ficavam assim em igualdade de circunstâncias com pretos, mulatos e cabras: igualados na pobreza, não mais diferenciados pelos matizes da pele. Os não-brancos, por sua parte, tinham ainda o ônus de provarem a contento sua condição de homens e mulheres livres. 88

0 Regulamento do Registro de Nascimentos e Óbitos continuou, pelo resto do Império e primeiros anos da República, sendo contestado e combatido pelos livres e pobres de Pernambuco. Mostrando que não apenas de movimentos messiânicos viviam e morriam as comunidades camponesas nordestinas, os livres e pobres mostraram também que existe toda uma história a ser escrita para os restaurar no papel que lhes correspondeu como sujeitos ativos da transição e como elementos centrais da constituição do novo sistema produtivo.

\section{Fontes primárias citadas}

\section{Arquivo Público Estadual de Pernambuco}

Códice de Manuscritos de Juizes de Paz (MSS JP), 1851, v.12; 1850-1852, v.12.

Códice de Manuscritos de Juizes de Direito (MSS JD), v. 1, 1851; 10, v.1, 1852.

Códice de Manuscritos de Juizes Municipais (MSS JM), v. 7, 1851; v. 8, 1852.

Códice de Manuscritos da Policia Civil (MSS PC), 40, 1852.

Relatório do Presidente da Provincia de Pernambuco, 1850-1853.

\section{Biblioteca Nacional do Rio de Janeiro}

Colecção das Leis do Império do Brasil. Tomos XI (1850), XIV (1852).

Relatório do Ministério do Império, 1850-1853.

Relatório do Ministério da Justiça, 1850-1853.

Diário de Pernambuco, outubro de 1851 - maio de 1852. 